\title{
Fizikselcilik Karşıtı Bilgi Argümanının Bir Savunusu
}

Öz: Frank Jackson'ın bilgi argümanı, bilinçli zihin durumlarımızın birinci kişi gözünden elde edilen öznel bilgisinin beyin durumlarının nesnel bilgisine indirgenemeyeceği iddiasından bilinçli zihin durumlarının fiziksel olmadığı sonucuna varır. Günümüz zihin felsefesi literatüründe bu argümana yöneltilen birçok itiraz bulunabilir. Bu çalışmada, bilgi argümanının içerdiği iddia ve varsayımları ortaya koyduktan sonra, argümanın her adımına getirilen başlıca itirazları ayrı ayrı ele alıyor ve bilgi argümanını bu itirazlar karşısında savunuyorum. Buradaki amacım, argümanın sağlamlığını kanıtlamak değil, fakat Jackson'a yöneltilen itirazların sorunlarını ve zayıf yönlerini ortaya koyarak bilgi argümanının sağlamlığına ve dolayısıyla fizikselciliğin yanlış olduğuna inanmanın hala makul bir felsefi pozisyon olduğunu göstermektir.

Anahtar Kelimeler: Bilgi Argümanı, Fizikselcilik, Görüngüsel Bilgi, Bilinç, Qualia.

\section{A Defense of the Knowledge Argument against Physicalism}

Abstract: According to Frank Jackson's knowledge argument, the fact that the subjective knowledge of conscious mental states cannot be reduced to the objective knowledge of brain states shows us that conscious mental states are not physical states. There are many rejoinders to this argument in contemporary philosophy of mind. In this article, after laying down the claims and assumptions that the knowledge argument rests on, I defend the argument against each major objection in the literature. My aim here is not to prove that the knowledge argument is sound, but to show that none of the objections are strong enough and that it can still be reasonable to believe that the knowledge argument is sound and physicalism is false.

Keywords: The Knowledge Argument, Physicalism, Phenomenal Knowledge, Consciousness, Qualia. 


\section{Giriş}

Frank Jackson'ın $(1982,1986)$ bilgi argümanı, güncel zihin felsefesinde halen tartışılmakta olan fizikselcilik (physicalism) karşıtı argümanların en önemlileri arasındadır. Zihin felsefesi bağlamında fizikselcilik, zihin durumlarının ${ }^{1}$ fiziksel durumlardan fazlası olmadığı görüşü olarak tanımlanabilir. Fizikselcilik doğruysa, zihin durumları ya fizikseldir ya da ontolojik olarak fiziksele indirgenebilir; yani, her zihin durumu ya bir fiziksel duruma ya da fiziksel durumlara ontolojik olarak bağımlı bir işlevsel, yapısal, vb. duruma özdeştir. Bu indirgenebilirlik ya da ontolojik bağımlılığın nasıl anlaşılması gerektiği fizikselcilik konusundaki en merkezi güncel tartışmalardan biridir. En sık alıntılanan fizikselcilik tanımlarından biri, bu ontolojik bağımlılığı üstgelim (supervenience) olarak alan tanımdır. Bu tanıma göre gerçek dünyadaki tüm fiziksel özellik örneklenmeleri ve yalnızca fiziksel özellik örneklenmeleri başka bir mümkün dünyaya kopyalansa, gerçek dünyada örneklendiği halde bu yeni mümkün dünyada örneklenmeyen hiçbir özellik olmayacaktır (Bkz. Lewis 1983b, Jackson 1998, Chalmers 1996, Tye 2009). Bazı felsefeciler dünyanın fiziksel ikizinin dünyanın tam anlamıyla ikizi olacağı (yani onda dünyamızdaki zihinsel özelliklerin de fiziksel özelliklerin kopyalanması neticesinde aynen yer alacağı) iddiasını fizikselciliğin tanımı olarak almasa da, bu iddianın doğruluğunun fizikselciliğin doğruluğu için gerekli koşul olduğunda genel bir fikir birliği olduğunu söyleyebiliriz (Bkz. Stoljar 2021).

Jackson'ın fizikselcilik karşıtı bilgi argümanı şöyledir²: Mary, bilinçli renk algımıza dair tamamlanmış/ideal bilimin bilgisine ve üstün bilişsel kapasiteye ve hafızaya sahip bir biliminsanıdır. Yani, Mary, insanın bilinçli renk algısına dair tüm fiziksel gerçekleri bilmektedir. Fakat, Mary, doğumundan itibaren siyah-beyaz bir

\footnotetext{
1 Fizikselcilik durumlar yerine özelliklere atıfla da tanımlanabilir, fakat bu çalışmada "durum (state)" terimini "özellik örneklenmesi" anlamında kullanacağım için soruşturmamız sırasında durumların fizikselliği ve özelliklerin fizikselliği arasında geçiş yapmak bir sorun teşkil etmeyecek. 2 Jackson, sonradan fizikselciliği kabul edip kendi argümanına karşı 5.1.'de ele alacağımız "yetenek hipotezi"nin başarılı bir yanıt olduğunu savunmuştur (Bkz. Jackson 2004).
} 
odada tutulmuş ve renkleri görmesine izin verilmemiştir. Sahip olduğu tüm bilgiyi kitaplardan ve siyah-beyaz bir televizyondaki derslerden edinmiştir. Bir gün, siyah-beyaz odasını terk etmesine izin verilir ve Mary hayatında ilk defa kırmızı bir domates görür. Domateslerin kırmızı olduğunu bilen Mary, domatese bakarak şöyle der: "Demek kırmızı görme deneyimi böyle bir şeymiş! Meğer insanlar kırmızı gördüklerinde böyle bir şey görüyormuş!” Mary'nin bu sözleri, bilinçli renk algısına dair yeni bir şey öğrendiğini gösteriyor, yani kırmızı görme deneyimini yaşamanın nasıl bir şey olduğunu. Fakat, Mary bilinçli renk algısına dair tüm fiziksel gerçekleri henüz odadayken biliyordu. Kırmızı görme deneyimi fiziksel bir olgu olsaydı, ona dair bilgi de Mary'nin tamamlanmış bilimsel bilgisinin bir parçası olmalıydı, ama değil. 0 halde, kırmızı görme deneyimini yaşadığında öğrendiği gerçek, fiziksel olmayan bir gerçek olmalı. Yani, fizikselcilik yanlıştır.

Kısaca, bilgi argümanı şunu söylüyor: Görüngüsel (phenomenal) bilinç durumlarımıza, yani birinci kişi gözünden bir niteliği, bir nasılllı̆̆ olan öznel deneyimlerimize dair gerçekleri bilme şeklimiz (yani görüngüsel bilgimiz) fiziksel gerçekleri bilme şeklimizden (yani nesnel olarak ifade edilebilen bilgimizden) indirgenemez şekilde farklıdır. Fakat, eğer görüngüsel bilinç özellikleri fiziksel olsaydı böyle bir epistemik fark da olmazdı. 0 halde, görüngüsel bilinç özellikleri fiziksel değildir.

Bu çalışmada, Jackson'ın argümanını literatürdeki fizikselci itirazlara karşı savunacağım. Bilgi argümanının dayandığı varsayımları açık bir şekilde ortaya koyabilmek amacıyla tartışmamı argümanın şu detaylı karakterizasyonu üzerine kuracağım ${ }^{3}$ :

Birinci Öncül:

Ö1: Mary, odadayken, insan renk deneyimine dair tamamlanmış fiziksel bilgiye sahiptir.

Birinci Çıkarım: (Ö1'den)

Ç1: İnsan renk deneyimine dair, Mary'nin odadayken bilmediği genel bir fiziksel gerçek yoktur.

\footnotetext{
${ }^{3}$ Argümanın bu versiyonu Nida-Rümelin'in (2015) formülasyonuna dayanmaktadır.
} 
Íkinci Öncül:

Ö2: Mary, odadan çıkıp kırmızıyı ilk defa gördüğünde insan renk deneyimine dair yeni bir şey öğrenir.

Íkinci Çıkarım: (Ö2'den)

Ç2: İnsan renk deneyimine dair, Mary'nin odadayken bilmediği genel bir gerçek vardır.

Sonuç: (Ç1 ve Ç2'den)

S: İnsan renk deneyimine dair bazı gerçekler fiziksel değildir.

Ç1 ve Ç2'den S'ye varan ana argüman mantıksal olarak geçerli bir argüman. $\mathrm{Bu}$ argümana dört farklı şekilde itiraz edilebilir: (i) Ö1 yanlıştır, (ii) Ö1'den Ç1 çlkmaz, (iii) Ö2 yanlıştır, (iv) Ö2'den Ç2 çıkmaz. Bu makalede, bu dört tür itirazdan her birini ayrı bir kısımda ele alarak bu itiraz türlerinin literatürdeki farklı örneklerini inceleyeceğim ve bilgi argümanının tüm bu itirazlara karşın hala fizikselciler tarafından ciddiye alınması gereken önemli bir argüman olduğunu savunacağım.

\section{Birinci Öncüle İtirazlar}

Ö1. Mary, odadayken, insan renk deneyimine dair tamamlanmış fiziksel bilgiye sahiptir.

Burada, "fiziksel bilgi"den kastedileni, fiziksel bilimlerin terminolojisi ile ifade edilebilecek bilgi olarak anlayabiliriz. Jackson (1986: 291), Mary'nin odadayken "tamamlanmış fizik, kimya ve nörofizyolojide bahsedilen her şey ve, işlevsel roller de dahil olmak üzere, bütün bunlara dayanan nedensel ve ilişkisel olgulara dair bilinebilecek şeylerin tümü"nün bilgisine sahip olduğunu söylüyor. Buna dayanarak Mary’nin bilgisinin tamamlanmış/eksiksiz bilimsel bilgi olduğunu söyleyebiliriz. Fakat, argümanda kilit rol oynayan unsur Mary'nin bilgisinin bilimselliğinden ziyade kitaplardan öğrenilebilecek bir tür bilgi olması. Bilimsel bilginin doğası üzerine olası tartışmaların bilgi argümanı hakkındaki tartışmayı gereksiz yere karmaşıklaştırmasını önlemek amacıyla, ve Occam'ın usturasına 
riayet ederek mümkün olduğunca az önkabule dayanmak açısından, Mary'nin odadayken sahip olduğu bilginin bilimselliğinden çok nesnel olarak ifade edilebilirliğine odaklanmak daha isabetli olacaktır. Mary, insan renk algısına dair tüm bilgisini kitaplardan ve siyah-beyaz televizyondaki derslerden ediniyor. Yani bu bilgi, kişinin herhangi bir spesifik görüngüsel bilinç durumu deneyimleyip deneyimlemediğinden bağımsız bir şekilde öğrenilebilecek bir bilgi. Nesnel bilgi, tanımladığımız anlamda, kitaplardan ve derslerden öğrenilebilecek bir bilgi olduğundan, Mary'nin insan renk algısına dair tamamlanmış nesnel bilgiye sahip olduğunu, buna izin verecek bilişsel kapasiteye sahip olduğunu varsaymakta kavramsal bir sorun göze çarpmıyor. Bu öncül, metafiziksel olasılığa dayalı bir kabul olduğundan, genel olarak en az itiraz edilen öncül olarak karşımıza çıkıyor.

Mary'nin fiziksel bilgisinin önemli bir özelliği de tikel değil genel gerçeklere dair bilgi olması. Yani, Mary, fiziksel bilimlerin terminolojisi ile ifade edilebilecek tüm tikel gerçekleri bilen alim-i mutlak bir varlık değil. İnsan renk algısına dair nörolojik, kimyasal, fiziksel (ve tabii ki matematiksel ve mantıksal) terimlerle ifade edilebilecek genel gerçekleri biliyor. Yani, mesela "insanlar $650 \mathrm{~nm}$. dalga boyundaki (yani kırmızı) ışığı gördüklerinde, normal şartlar altında, şu beyin durumuna geçerler" gibi gerçekleri biliyor. Ve, daha sonra göreceğimiz gibi, Jackson'a göre, Mary daha sonra ilk defa kırmızı rengi gördüğünde öğrendiği șey de insan renk algısına dair genel bir gerçek.

Çok az sayıda da olsa, literatürde bu öncüle getirilen bazı itirazlar bulunabilir. Örneğin, Stemmer (1989: 90) Mary'nin tamamlanmış nesnel bilgiye sahip olamayacağını, çünkü bilginin de beyin durumuna indirgenebileceğini, bu durumda Mary'nin bilgisinin kendisini içermesi gerektiğini ve bunun da öz-gönderimden dolayı döngüsellik problemine yol açacağını iddia ediyor. Fakat, bu Mary'nin fiziksel olarak ifade edilebilen tüm tikel gerçekleri, o anda içinde bulunduğu beyin durumunun bilgisi dahil, bildiğini varsayıyor ki, Jackson'ın iddiası bu değil. Mary'nin tamamlanmış fiziksel bilgisi insan renk algısının doğasına dair genel 
gerçeklerin bilgisi, kimin hangi anda hangi beyin durumunda olduğunun tikel bilgisi değil. Kaldı ki, bilginin de beyin durumundan ibaret olduğu gibi tartışmalı bir iddiaya dayanarak, öz-gönderim sebebiyle, Mary'nin $t_{1}$ anında o andaki beyin durumunun bilgisine sahip olmasının imkansız olduğu gösterilse bile, Jackson basitçe Mary'nin belli bir anda o anki beyin durumunun bilgisine sahip olamayacağını kabul edebilir. Hatta, bilgi argümanına bir sorun oluşturmak bir yana, Stemmer'ın iddiasının Jackson'ı desteklemek için kullanılması da mümkün olabilir: Mary, kırmızı gördüğü anda kırmızı deneyiminin görüngüsel bilgisine sahip olur. Birçok fizikselciye göre (özellikle bkz. 5.3), bu görüngüsel bilgi aslında Mary'nin o anki beyin durumunun bilgisidir. Fakat, Stemmer hakliysa Mary o anki beyin durumunu bilemez (çünkü bu bilgi o anki beyin durumuyla aynı şeydir, bu da öz-gönderimsel bir paradoksa yol açar). Yani, Mary, domatese bakarken kırmızı deneyimini bilebilir (birinci kişi gözünden), fakat o anki beyin durumunu bilemez, o halde kırmızı deneyimi o anki beyin durumuna indirgenemez.

\section{Birinci Çıkarıma İtirazlar}

Ö1. Mary, odadayken, insan renk deneyimine dair tamamlanmış fiziksel bilgiye sahiptir.

Ç1. O halde, insan renk deneyimine dair, Mary'nin odadayken bilmediği genel bir fiziksel gerçek yoktur.

$\mathrm{Bu}$ çıkarım, tüm fiziksel gerçeklerin fiziksel/bilimsel terimlerle, yani nesnel olarak ifade edilebileceği kabulüne dayanıyor. Bu kabule göre, tüm fiziksel gerçekler, ki bunlar mikro-fiziksel de olabilir, kimyasal, biyolojik, nörolojik gerçekler de olabilir, belirli bir öznel deneyimin nasıllığına atıfta bulunulmadan tanımlanabilecek empirik, işlevsel, yapısal veya matematiksel terimler ve mantıksal operatörler aracılığı ile tam olarak ifade edilebilir. Eğer bu kabul doğru ise, fiziksel bir parçacığın doğası hakkında, nesnel olarak ifade edilemeyecek hiçbir gerçek yoktur. Örneğin, parçacığın spini, kütlesi ve yükü, öznel deneyime atıfta 
bulunmadan tanımlanabilir ve bunların değeri matematiksel olarak ifade edilebilir. Eğer bu kabul doğru ise, Mary'nin tamamlanmış nesnel bilgisinden mantıksal olarak çıkarılamayacak bir genel fiziksel gerçek yoktur. Şimdi, bu kabule yapılan bazı itirazları göreceğiz.

\section{1. Fizikselin Farklı Tanımlamaları}

"Fiziksel" ne demektir? Fizikselin kuramcı tanımlamasına göre fiziksel bir özellik fizik biliminde (ya da fiziksel bilimlerde) kendisine atıfta bulunulan (ya da böyle özelliklere ontolojik olarak bağımlı olan) özelliktir. Eğer fizikseli bu şekilde anlarsak, ve genel olarak kabul edildiği üzere bilimsel bilginin nesnel olarak ifade edilebileceğini de kabul edersek, tüm fiziksel gerçeklerin nesnel olarak ifade edilebileceği sonucuna varırız. Fakat, kuramcı tanımlama, tek başına veya başka tanımlamalarla birleştirilmiş haliyle, en yaygın kabul gören tanımlama olmasına rağmen fizikseli bu tanımlamayla uyuşmayan şekillerde kavramsallaştıran felsefeciler de mevcut. Örneğin, Flanagan (1992), Bealer (1994), Alter (1998), Van Gulick (2004), ve özellikle de Howell $(2008,2013)$ tarafından savunulan bir görüşe göre, bazı fiziksel gerçekler sadece öznel deneyim yoluyla bilinebilirler (ya da en azından böyle olması epistemik olarak mümkündür). Benzer şekilde, Galen Strawson'a (2006) göre fizikseli nesnel olarak ifade edilebilirliğe indirgeyen görüş, metafizik bir görüş olan fizikselciliğin aksine, sadece epistemolojik bir görüştür. Bu durumda, fizikseli nesnel olarak ifade edilebilirlikten bağımsızlaştırdığımızda, Mary'nin tamamlanmış nesnel bilgiye sahip olmasından fizikselin tamamlanmış bilgisine sahip olduğu sonucuna varılamaz. Fakat, Nida-Rümelin'in (2015) de belirttiği gibi, sadece öznel deneyim yoluyla bilinebilecek fiziksel gerçeklerin neden fiziksel gerçek sayılmaları gerektiğinin açıklanmasının güçlüğü bu görüşün kabul edilebilirliğinin önünde önemli bir engel teşkil etmektedir. ${ }^{4}$

Yalnızca öznel deneyimle bilinebilecekleri iddiasında bulunmamakla birlikte, nesnel olarak ifade edilemeyecek fiziksel gerçeklerin var olabileceği iddiasının

\footnotetext{
4 Sadece öznel deneyim yoluyla bilinebilecek fiziksel özelliklerin varlığı iddiasına dayanan öznel fizikselcilik hakkında eleştirel bir değerlendirme için bkz. Kıymaz 2019c.
} 
dayandırılabileceği alternatif fiziksel tanımlamaları da mevcut. Örneğin, via negativa tanımlamaya göre, fiziksel, indirgenemez bir şekilde zihinsel olmayandır (Howell 2008, Levine 1983, Spurrett\&Papineau 1999, Montero 1999). İndirgenemez bir şekilde zihinsel olmadığı halde nesnel olarak ifade edilemeyen fiziksel özellikler mevcutsa, Mary'nin bu özellikleri içeren gerçekleri tamamlanmış nesnel bilgisinden çıkarsaması mümkün değildir. Fakat, genel olarak, literatürde via negativa tanımlama kuramcı tanımlamayla birleştirilerek kullanıldığından (örn. Tye 2009, Chalmers\&Jackson 2001, Wilson 2006) bilgi argümanına bu tarz itirazlarla pek sık karşılaşmıyoruz. ${ }^{5}$

\section{2. Çıkarım Deneyim Gerektirir}

P, Mary'nin tamamlanmış fiziksel bilgisi olsun. P, belki de milyarlarca sözcükten ve matematiksel ifadeden oluşuyor. Q, kırmızı görmenin öznel deneyimine ilişkin doğru bir önerme olsun (örneğin, Jakson'ın Mary'nin ancak kırmızı görünce öğrendiğini iddia ettiği "kırmızı görmek böyle bir şeymiş" önermesi). Jackson'a göre, eğer fizikselcilik doğru ise, “P ise Q" önermesi a priori doğru olmalıdır, yani P'yi bilen, Q’ya mantıksal olarak, ek bir deneyim ya da gözleme ihtiyaç duymadan ulaşabilmelidir, çünkü, eğer fizikselcilik doğruysa, $P$ zaten Q’yu da içerir6́. Montero (1999) bunu kabul ediyor, fakat şu olasılı̆̆ gündeme getiriyor: Mary'nin odadayken P'den Q'yu çıkarsayamamasının nedeni, Q'yu anlayamıyor olması olabilir. Q'nun yalnızca kırmızıyı deneyimlemiş insanlar tarafından anlaşılabilecek bir önerme olduğunu varsayalım (ki Jackson da böyle olduğunu iddia ediyor). Mary'nin, henüz odadayken, “P ise Q" önermesinin a priori olarak doğru olduğunu görememesi, bu yüzden de Q sonucuna varamaması bu durumda gayet doğal olur. Fakat bu, Mary'nin, eğer Q'yu kavrayabilecek olsaydı, yani Q’yu kavrayabilmesi için ihtiyacı olan kırmızı görme deneyimine sahip olsaydı, yine “P ise Q"nun a priori doğruluğunu göremeyecek olduğu anlamına

\footnotetext{
5 Zihin felsefesi bağlamında "fiziksel" teriminin farklı kullanımlarının eleştirel bir değerlendirmesi için bkz. Kıymaz 2021.

${ }^{6}$ Bkz. aşağıda, 4.2'de Jackson'dan alıntılanan "Fred" örneği.
} 
gelmiyor. Yani, Montero'ya göre, P'den mantıksal olarak Q'yu çlkarsayabilmek için önce Q'yu kavrayabilmek, Q’yu kavrayabilmek için de kırmızı görme deneyimine sahip olmak gerekiyor olabilir, fakat eğer kırmızı görme deneyimine sahip biri P'den Q'yu mantıksal olarak çıkarsayabiliyorsa, bu yine "P ise Q"nun a priori olduğu ve dolayısıyla fizikselciliğin doğru olduğu anlamına gelir.

Montero da, görüldüğü gibi, bazı fiziksel gerçeklerin sadece öznel deneyime dayanarak bilinebilecek olmasının imkanını savunuyor. Ve, burada, Q ile ifade edilen gerçeğin fizikselliği, Q'nun P'den, yani fizikselin eksiksiz nesnel bilgisinden, a priori olarak çıkarılabilmesinde yatıyor. Fakat, eğer Q yalnızca deneyim yoluyla bilinebilecek bir önerme ise, nesnel olarak bilinebilecek bir önermeden nasıl mantıksal olarak çlkarılabileceği, başka bir ifade ile "P ise Q"nun nasıl a priori doğru olabileceği açıklanmaya muhtaç olarak kalıyor. Şöyle ki: “P ise Q" nesnel bir önerme değil, çünkü $Q$, belli bir görüngüsel deneyim olmadan kavranamıyor. 0 halde, "P ise Q"nun a priori doğru olması, mantıksal bir doğru olmasından kaynaklanıyor olamaz, çünkü mantıksal doğrular nesnel olarak ifade edilebilirler. Bu yüzden de, “P ise Q"nun nasıl a priori doğru olabileceği açılklanmadığı sürece, bu itiraz da pek güçlü görünmüyor.

\section{4. İkinci Öncüle İtirazlar}

Ö2. Mary, odadan çıkıp kırmızıyı ilk defa gördüğünde insan renk deneyimine dair yeni bir şey öğrenir.

Jackson, Mary’nin ilk defa renk görme deneyimini yaşadığında yeni bir şey öğreneceğinin "apaçık" olduğunu iddia ediyor (1982: 130). Bu öncülün sezgisel doğruluğu, bir sonraki kısımda göreceğimiz gibi, birçok fizikselci filozof tarafından da kabul ediliyor. Peki, ikinci öncülün doğruluğunu birçok kişi için bu kadar "apaçık" kılan nedir?

İkinci öncülün sezgiselliğini ortaya koymak amacıyla, Thomas Nagel'in (1974) yarasa ve Jackson'ın (1982) Fred örneklerinden esinlenerek, şöyle bir 
senaryodan bahsetmek istiyorum: Biliyoruz ki arılar mor ötesi renkleri görebiliyor. Varsayalım ki, genetik mühendislik sonucu bir insana, göz ve beyin yapısı değiştirilerek, arılar gibi mor ötesi renkleri görme yeteneği verildi. $\mathrm{Bu}$ insan, gökkuşağına baktığında bizim gördüğümüz ana renklere ek olarak, morun ötesinde sekizinci bir renk daha görüyor. Bu insanın gözlerinin ve beyninin biyolojik yapısını, mor ötesi ışığın optiğini, yani bu insanın ekstra renk algısına dair fiziksel gerçekleri bilebilmemizin önünde bir engel yok. Fakat, bu sekizinci rengin birinci kişi gözünden nasıl göründügünü bilebilir miyiz? Denebilir ki bilemeyiz, çünkü bu rengi deneyimleyemez ve hayal edemeyiz. Fakat, burada Jackson'ın vurguladığı nokta bu rengi deneyimleyemeyecek ya da hayal edemeyecek olmamız değil, bu rengin nasıl göründüğünü bilebilmek için onu deneyimlemek ya da hayalimizde canlandırmak zorunda olmamız. Yani, bu sekizinci renge ve onun algılanmasına dair tüm fiziksel gerçekleri bilsek bile, kendimiz o rengi görmedikçe bilemeyeceğimiz bir șey var. İște, Mary’nin kırmızı gördüğünde öğrendiği de böyle bir şey.

Şimdi bu öncüle getirilen bazı itirazları görelim. Bu itirazlar, genel olarak, bizi Mary'nin kırmızı gördüğünde şaşırmayacağına, “bu domates tam da düşündüğüm gibi görünüyor" diyeceğine inandırmaya çalışıyor.

\section{1. Argümanın Ayrıntı Eksikliği}

Literatürdeki bazı itirazlar Jackson'ın argümanında Mary’nin odasındaki durumunun tarifindeki ayrıntı eksikliğine dayanıyor. Örneğin, Thompson (1995: 264), Mary'nin ten renginden yola çıkarak kırmızının nasıl göründüğünü bilebileceğini, ayrıca Mary'nin gözlerini sıkıca ovuşturarak içinde kırmızının da bulunduğu renkleri görebileceğini ya da basitçe rüyasında kırmızı nesneler görebileceğini, böylece henüz odadayken kırmızı görmenin nasıl bir deneyim olduğunu bilebileceğini iddia ediyor. Elbette, Mary'nin odadayken dahi kırmızıyı görebileceği iddia edilebilir, fakat aslında bu itiraz Jackson'ın düşünce deneyine katılmayı reddetmekle eşdeğer. Mary'nin odadaki durumunu tarif ederken kırmızı 
deneyimine yol açabilecek her olası duruma değinmeye gerek yok. Mary'nin, gözlerini ovuşturmak ya da rüyasında görmek gibi, kırmızı görme deneyimi yaşayabileceği her ne olasılık varsa o olasılığın gerçekleşmediğini varsaymalıyız, ki Jackson'ın argümanı bir anlam ifade edebilsin. Kaldı ki, eğer renk görme örneği bu açılardan sorunlu ise bilgi argümanı rahatlıkla belli bir koku (Broad 1925) ya da tat (Lewis 2004) deneyimi üzerinden de kurulabilir. Bilgi argümanı için, Mary'nin odadayken belli bir görüngüsel deneyimi yaşamamış olmasının kendi içinde tutarlı bir varsayım olması yeterli.

\section{2. Hayal Etmenin İmkanı}

Yukarıda ele aldığımız itiraza benzer, Jackson'ın argümanını yanlış anlamaya dayanan bir diğer itiraz da kırmızı görme deneyiminin tamamlanmış fiziksel bilgiye dayanarak hayal edilebilir olduğu itirazıdır. Bu itiraza göre, Mary'nin odadan çıkıp kırmızı bir domates gördüğünde şaşırmaması mümkündür, çünkü Mary, tamamlanmış fiziksel bilgisine dayanarak, henüz odadayken kırmızı görmenin nasıl bir şey olduğunu hayal edebilir. Fakat, Churchland (1985), Maloney (1985: 34) ve Dennett'in (2007: 23) yorumlarının aksine, Jackson (1986: 292, 295) Mary'nin odadayken kırmızı rengi hayal edemeyeceğini iddia etmiyor. Jackson'ın, bizden farklı renk deneyimlerine sahip olan Fred hakkında söylediklerine bakalım:

Eğer fizikselcilik doğru olsaydı, Fred hakkındaki yeterli fizik bilgimiz, onun renk deneyimlerini bilebilmek için tahminde bulunmayı veya özel hayal etme ve anlama girişimlerimizi gereksiz kılacaktı. Bu bilgiye zaten sahip olurduk. (1982: 132)

Jackson'ın vurguladığı nokta, Mary'nin kırmızı görme deneyimini hayal edemeyeceği değil, Mary’nin kırmızı görmenin bilinçli deneyimi hakkında eksiksiz bilgiye sahip olabilmek için, kırmızı deneyimini yaşaması ya da yaşadığını (gerçekçi bir şekilde) hayal etmesi gerektiğidir. Jackson'a göre, bu, fizikselcilik için bir sorun yaratıyor, çünkü böyle bir gereklilik, hiçbir fiziksel gerçeğin bilgisine 
(mesela, beynindeki nörolojik aktivitelerin fiziksel bilgisine) sahip olabilmek için var olan bir gereklilik değildir. ${ }^{7}$

\section{3. Fiziksel Bilgiden Çıkarımın İmkanı}

Dennett, Mary daha önce renkleri görmüş ya da hayalinde canlandırmış olmasa bile, odadan çıkıp kırmızı bir domates gördüğünde şaşırmayacağını, çünkü renk görme deneyiminin öznel niteliğini eksiksiz nesnel bilgisinden çıkarsayabileceğini iddia ediyor. Dennett'a göre, daha önce renkleri görmemiş olan Mary'e mavi bir muz gösterirsek, Mary “Beni kandırmaya çalışıyorsunuz! Muzlar sarı olur, bu ise mavi!” diyebilecektir, çünkü Mary’nin tamamlanmış bilgisi Mary'nin o anki beyin durumunu da içerir ve Mary hangi beyin durumunun sarı görme deneyimine ve hangi beyin durumunun mavi görme deneyimine denk düştüğünü bilmektedir (2004: 60-61). Fakat, birinci öncüle yapılan itirazlar konusunda da değindiğimiz gibi, Jackson, Mary’nin her tikel fiziksel gerçeği bildiğini iddia etmiyor. Mary, içinde bulunduğu beyin durumunun fiziksel bilgisinden yola çlkarak o anda deneyimlediği rengin hangi renk olduğunu bulabilir, fakat bu Jackson için bir sorun teşkil etmez, çünkü Mary’nin yine de renkleri gördüğünde insan renk algısına dair yeni bir şey, yani deneyimin birinci kişi gözünden niteliğini öğrendiği iddia edilebilir. Kaldı ki, Jacquette'in (1995: 225) de vurguladığı gibi, Mary'nin bu şekilde tikel fiziksel gerçeklere dayalı akıl yürütmeyle mavi muz oyununa gelmemesi bilgi argümanı ile aslında alakasızdır, çünkü Mary odadan çıkmadan dahi, odanın dışındaki muzun yüzey özelliklerinin tikel fiziksel bilgisini biliyorsa buna dayanarak muzun aslında maviye boyanmış olduğunu bilebilirdi. Dennett, bu durumda, Mary'e tamamlanmış tikel fiziksel

\footnotetext{
7 Bilgi argümanı Mary'nin kırmızı görme deneyiminin hayal edemeyeceği iddiasına dayanmasa da, bu iddiaya dayanan şöyle bir argüman da ortaya atılabilir: Mary odadayken kırmızı görme deneyimini hayal edemez; eğer kırmızı görme deneyimi fiziksel olsaydı, Mary kırmızı görme deneyimini hayal edebilirdi; o halde kırmızı görme deneyimi fiziksel değildir. Bu argüman, Dennett ve Churchland'in bilgi argümanıyla karıștırarak itiraz ettikleri argüman olacaktır. Literatürde itirazlara uğradığı halde daha önce açıcça savunulmamış olan bu argümanın ayrıntılı bir değerlendirmesi ve savunusu için bkz. Kıymaz 2019b.
} 
bilgiyi atfederek, Jackson'ın sorunsallaştırdığı şeyi, yani öznel deneyimi, senaryonun dışında bırakıyor.

Dennett (2007: 28-9) ayrıca, Mary'nin şu şekilde genel fiziksel bilgiden de öznel deneyimin bilgisini çıkarsayabileceğini iddia ediyor: Ĕger fizikselcilik doğruysa, kırmızı görme deneyiminin öznel bilgisine sahip olma durumu da bir beyin durumundan ibarettir ve Mary, henüz odadayken, eksiksiz genel fiziksel bilgisi sayesinde bu durumun hangi beyin durumu olduğunu bilmektedir. Kırmızı deneyiminin bilgisini oluşturan beyin durumuna "B durumu" adını verelim. B durumu, kırmızı görme ya da kırmızıyı gözünde canlandırma durumu değil, sadece kırmızı görmenin nasıl bir deneyim olduğunu biliyor olma durumu. Mary'nin, B durumu hakkındaki genel bilgisine dayanarak beynini B durumuna getirdiğini varsayalım. Bu durumda, Mary, kırmızı görme deneyiminin öznel bilgisine sahip olacaktır. Fakat, bu durumda, Mary, kırmızıyı görme ya da hayal etme gibi hilelere başvurmadan, sadece genel fiziksel bilgisine dayanarak kırmızı deneyiminin öznel bilgisine ulașmış oldu.

Alter (2008), Dennett'a şöyle bir itirazda bulunuyor: Jackson'ın argümanı, deneyimin öznel bilgisinin fiziksel bilgiden mantıksal olarak çıkarılamayacağı iddiasına dayanıyor, fakat Dennett'ın anlattığı senaryoda Mary'nin beynini belli bir nörolojik duruma getirerek öznel bilgiyi biliyor hale gelmesi, öznel bilgiyi fiziksel bilgiden mantıksal olarak çıkarsamasından çok farklı. Yani, Dennett'ın tarif ettiği senaryoda Mary, sonucu öznel bilgi, öncülü fiziksel bilgi olan bir çlkarımda bulunmuş sayılmaz, ve bu yüzden de bu senaryo Jackson'ın argümanı için bir sorun teşkil etmez. Dennett, makalesinde buna benzer bir itirazı ele alarak şu cevabı veriyor: "Görebildiğim kadarıyla, bu itiraz (saf?) mantıksal çıkarım ile diğer bilgisel öz-aydınlanma yolları arasında makul olmayan, müsrif bir ayrım varsayıyor" (2007: 29). Fakat, Dennett'ın bu cevabı tatmin edicilikten çok uzakta8. Dennett'in senaryosunda Mary'nin öznel bilgiye ulaşma yolu, adı "çıkarım" olsa da olmasa da,

\footnotetext{
${ }^{8}$ Dennett'ın bu cevabına olan itirazımı başka bir makalede daha ayrıntılı bir şekilde ortaya koyuyor ve ikinci öncülü savunuyorum. Bkz. Kıymaz (2020)
} 
bilgi argümanı bağlamında hiçbir önem arz etmiyor, çünkü, fizikselcilik yanlış olsaydı dahi Mary'nin bu şekilde öznel bilgiye ulaşması mümkün olabilirdi. Diyelim ki fizikselcilik yanlış; bilinç özellikleri fiziksel özellikler değil. Ve, yine diyelim ki, beyin durumları ile (fiziksel olmayan) bilinç durumları arasında nomolojik (metafiziksel olarak zorunlu olmayan) bir korelasyon var (ki bunu Descartes dahi kabul edebilirdi). Mary, bu durumda da beynini B durumuna getirerek öznel deneyimin bilgisine sahip olabilirdi, fakat bu Jackson'ın argümanına sorun yaratacak şekilde bir "nesnel bilgiden öznel bilginin çıkarsanması” örneği olmazdı. Mary'nin beynini özel bir duruma getirmesi, Mary'nin renkleri görmesi ya da hayal etmesinden çok da farklı değil. Jackson, basitçe şunu diyebilir: Eğer kırmızı görme deneyimi fiziksel bir durum olsaydı, ona dair tüm doğrular fiziksel terminolojiyle nesnel olarak ifade edilebilir olacaktı, ve o zaman da Mary, kendini herhangi bir beyin durumuna sokmaya çalışmak yerine, tamamlanmış fiziksel bilgisinden mantıksal çıkarımla kırmızı görme deneyiminin bilgisine rahatlıkla ulaşabilecekti.

Bilgi argümanı bağlamında, "fizikselcilik doğru ise, Mary odadayken kırmızı deneyiminin görüngüsel bilgisini edinebilir" iddiası, Jackson'ın söylemek istediği şeyin aslında fazla kabaca dile getirimi. Çünkü, 4.1'de de gördügü̈müz gibi, Mary gözlerini ovuşturarak da kırmızı görebilirdi; rüyasında da görebilirdi. Burada Jackson'ın söylediği şu şekilde anlaşılmalı: “fizikselcilik doğru ise, Mary’nin eksiksiz fiziksel bilgisi kırmızı deneyiminin görüngüsel bilgisini içerir." 4.2.'de gördüğümüz alıntıda, Jackson açıkça, eğer fizikselcilik doğru ise, fiziksel bilgiden görüngüsel bilginin çıkarsanması için hayal kurma ya da başka türlü özel bir anlama girişimine ihtiyaç olmayacağını, zaten görüngüsel bilginin fiziksel bilginin bir parçası olacağını söylüyor. Bu durumda da Mary'nin fiziksel bilgisini bir argümanın öncülü değil de bir talimatname olarak kullanıp, beynini kırmızı deneyimini bilme durumunun nörolojik tarifine dayanarak özel bir duruma 
geçirmesi ve böyle dolaylı bir şekilde görüngüsel bilgiye ulaşması, Jackson'ın iddiasına bir karşı-örnek teşkil etmiyor. ${ }^{9}$

\section{4. Toplumsal Dişsalcılık}

Ball (2009), bilgi argümanına şöyle bir itirazda bulunuyor: Mary'nin odadayken kırmızı görme deneyiminin öznel bilgisine sahip olamamasının tek yolu, görüngüsel bilginin fiziksel/işlevsel kavramlara a priori olarak indirgenemeyecek ve ancak o deneyimi yaşayarak edinilebilecek kavramlar içermesidir ${ }^{10}$. Fakat, aslında böyle kavramlar yoktur, çünkü öznel deneyimlerimize göndermede bulunan her kavram, göndermede bulunulan deneyime sahip olunmasından bağımsız bir şekilde edinilebilir ${ }^{11}$. Bu durumda da Mary, henüz odadayken kırmızı görme deneyiminin görüngüsel bilgisine erişebilecektir.

Peki, kırmızı görmüş olan insanların kırmızı görme deneyimleri hakkında düşünürken kullandıkları kavramı, hiç kırmızı görmemiş olan Mary henüz odadayken nasıl edinebilir? Ball'a göre, Putnam $(1970,1975)$ ve Burge'un (1979, 1986) göstermiş olduğu üzere, bir kavram, kavramın işaret ettiği gösterilenin (reference) eksiksiz bir anlayışına sahip olmadan da kullanılabilir ve bu öznel deneyimlerimize göndermede bulunan kavramlar için de geçerlidir. Örneğin, bir insan çınar ve köknar ağaçlarını görse birbirinden ayıramayabilir, fakat yine de eğer bir çınarı işaret ederek tamamen tesadüfi bir şekilde "bu çınardır" diye düşünürse, düşündügü önerme doğru olacaktır. Bu da bu insanın çınar hakkındaki anlayışının çok eksik olmasına rağmen yine de "çınar" kavramına sahip olduğunu gösterir (yoksa düşüncesi şey doğru olamazdı). Mary de, odadayken, kırmızı görme

\footnotetext{
${ }^{9}$ Bu durumda, Çağatay\&Ekemen'in (2011) savunduğu gibi, Mary'nin odadayken Dennett'ın anlattığ şekilde beynini (bir makine yardımıyla ya da yardım almadan) manipüle ederek kırmızının görüngüsel bilgisine ulaşabilecek olması ve Uslu'nun (2021) dikkat çektiği gibi, Mary'nin bunu yaparken sadece fiziksel yöntemler kullanarak beyninin sadece fiziksel özelliklerini manipüle ediyor olması bir önem arz etmiyor. Jackson'ın vurguladı̆̆ı şey, Mary'nin fiziksel bilgisinden görüngüsel bilgiye varmak için sıradan (ve-bağlacı eleme - conjunction elimination gibi) bir mantıksal çıkarımdan fazlasını yapmak zorunda kalışı.

10 Bu kavramlara "görüngüsel kavramlar" (phenomenal concepts) deniyor. Görüngüsel kavramları aşağıda (5.3) daha ayrıntılı şekilde irdeleyeceğiz.

${ }^{11}$ Bu iddianın bir başka savunusu için bkz. Tye (2009).
} 
deneyimine işaret eden kavrama sahip olabilir, ve böylece bu deneyime dair tüm doğru önermeleri eksiksiz nesnel bilgisinden çıkarabilir.

Fakat, Alter'in (2013) de dikkat çektiği gibi, yine de, çınar hakkında eksiksiz anlayışa sahip olmayan bir insan gibi, Mary de kırmızı görme deneyimini yaşamadan önce bu deneyime dair eksiksiz bir anlayışa sahip olmayacaktır. Yani, kırmızı gördüğünde, yeni bir kavram öğrenmeyeceğini kabul etsek bile, kırmızı görme deneyimine dair anlayışı zenginleșecektir. Ve, bilgi argümanı bu duruma rahatlıkla uyarlanabilir: Mary, odadayken, insanın bilinçli renk algısına dair tüm kavramlara sahip olmasına rağmen, deneyimlemediği bilinç durumlarına dair eksiksiz anlayışa sahip değildir. Fakat, tüm fiziksel gerçeklerin eksiksiz anlayışına sahiptir (çünkü fiziksel gerçeklerde nesnel olarak ifade edilemeyen bir şey yoktur). O halde, bilinç durumlarına dair bazı gerçekler fiziksel gerçekler değildir.

\section{5. İkinci Çıkarıma İtirazlar}

Ö2. Mary, odadan çıkıp kırmızıyı ilk defa gördüğünde insan renk deneyimine dair yeni bir şey öğrenir.

Ç2. O halde, insan renk deneyimine dair, Mary'nin odadayken bilmediği genel bir gerçek vardır.

Bu çıkarım, Mary'nin yeni öğrendiği şeyin, daha önce bilmediği bir gerçek olduğu iddiasına dayanıyor. Fakat, bazı fizikselci filozoflar, Mary'nin kırmızıyı ilk defa deneyimlediğinde bir tür bilgi edineceğini kabul etmekle birlikte, Mary'nin edineceği bu bilginin daha önce bilmediği, yeni bir gerçeğe dair olmadığını iddia ediyorlar.

\section{1. Yetenek Hipotezi}

Önerme, doğruluk değerinin (doğru/yanlış) en temel taşıyıcısıdır. "Dünya yuvarlaktır," "2+2=5," "bütün kargalar siyahtır” gibi cümleler önerme ifade ederler, çünkü bu cümleler ya doğru ya da yanlıştır. Fakat, bazı cümleler, mesela “Saat kaç?” 
ya da "lütfen oturun" gibi soru, emir, vs., bildiren cümleler önermesel değildir, çünkü doğru ya da yanlış olma kapasitesine sahip değillerdir. Aynı şekilde, her bilgi de önermesel değildir. Dünyanın düz olduğunu, 2+2'nin 4 olduğunu bilen bir insan önermesel bilgiye sahiptir, fakat, günümüzde genel kabul gören görüşe göre, önermesele indirgenemeyecek bilgi türleri de vardır. Pratik bilgi ya da yordam bilgisi (know-how) diyebileceğimiz bilgi bu türdendir (Ryle 1949). Örneğin, bir insanın yüzmeyi biliyor olması, onun belli bir yeteneğe sahip olduğunu ifade eder, fakat bu yeteneğe sahip olmak, yüzmeye dair önermesel bilgiye sahip olmaktan farklıdır. Kitap okuyarak yüzmeye dair gerçekleri öğrenmek ile yüzme öğrenmek birbirinden çok farklı ve birbirine indirgenemeyecek iki süreçtir. Lewis (1983a, 2004) ve Nemirow (1980, 1990), bu ayrımdan yola çlkarak, Yetenek Hipotezini ortaya atıyor ve Mary’nin kırmızı gördüğünde yeni bir şey öğrendiğini kabul edip yeni bir gerçek öğrendiğini reddedebileceğimizi iddia ediyor.

Lewis ve Nemirow’a göre, Mary’nin kırmızı gördüğünde edindiği şey sadece kırmızı deneyimini hayal etme, tanıma ve hatırlama yetenekleridir, yeni bir gerçeğin önermesel bilgisi değil. Bu da bilgi argümanını çürütmeye yeter. Şu örneği ele alalım²: Mary, odadayken, yüzmeye dair tüm fiziksel ve biyolojik gerçekleri kitaplardan öğreniyor. Fakat, odasında tabii ki yüzme öğrenebileceği imkanlar yok. Odasını terk etmesine izin verildikten sonra Mary bir yüzme kursuna yazılıyor ve yüzme öğreniyor. Şimdi, odadayken yüzmeye dair tüm fiziksel gerçekleri biliyordu, fakat daha sonra yüzmeye dair yeni bir șey öğrendi, o halde yüzme fiziksel bir aktivite değildir, diyebilir miyiz? Bu argüman ne kadar mantıksızsa, yetenek hipotezine göre, Jackson'ın bilgi argümanı da o kadar mantıksızdır. Mary odadan çıktığında nasıl yüzüleceğini öğrendi: öğrendiği yüzmeye dair yeni bir şey, sadece yüzme yeteneği. Aynı şekilde, kırmızıyı gördügüunde de yeni bir gerçek öğrenmedi, sadece yeni yetenekler kazandı.

12 Lewis ve Nemirow yetenek hipotezini bu analoji üzerinden açıklamıyor, fakat ben yetenek hipotezinin iddiasını açıkça ortaya koymamıza yardımcı olacağını düşündüğümden bu analojiyi kullanacağım. 
Jackson'a göre, Mary, ilk defa kırmızı görme deneyimini yaşadığında, dikkatini bilinçli deneyimine odaklayıp, "meğer kırmızı görmek böyle bir şeymiş" dediğinde, yeni bir gerçek öğreniyor. Oysa, yetenek hipotezine göre, Mary sadece bazı yetenekler kazanıyor, doğruluk değeri olan bir bilgi edinmiyor. Fakat, Crane'in (2003) de dikkat çektiği gibi, Mary, doğruluk değeri olan bir şey söylüyor, çünkü, domatesin yeşil olduğunu sanıp eğer "meğer yeşil görmek böyle bir şeymiş" deseydi, söylediği yanlış olacaktı. Yani, burada önermesel bir bilgiden bahsediyoruz, sadece yordam bigisinden değil. Benzer şekilde, Loar (2004: 236-7), Frege-Geach tarzı bir itirazda bulunuyor: Mary'nin öğrendiği şey geçerli argümanlarda öncül ya da koşullu önermelerde ön-bileşen olarak kullanılabilir, bu da onun önermesel bilgi olduğunu gösterir. Eğer Mary’nin öğrendiği şey önermesel bilgi olmasaydı, şu argüman mantıksal olarak geçerli bir argüman olamazdı: Eğer kırmızı görmek böyle bir şey ise, insanlar bir limona baktıklarında bu renk deneyimini yaşamıyorlar; kırmızı görmek böyle bir şey; o halde, insanlar bir limona baktıklarında bu renk deneyimini yaşamıyorlar. Bu mantıksal olarak geçerli bir argüman, o halde Mary'nin öğrendiği şey önermesel bilgidir ${ }^{13}$.

Lewis bu itirazlara cevap veriyor (Lewis kırmızı görmek yerine Vegemite tatmak deneyimini örnek olarak kullanıyor. "Vegemite", konsantre maya özütünden üretilen, Avustralya'ya özgü bir yiyeceğin, adı ürünle özdeşleşmiş markasıdır).

Denebilir ki, "Vegemite'ı tatmanın nasıl bir şey olduğunu bilmek" aslında "Vegemite'ı tatmanın nasıl bir şey olduğunu 'Vegemite'ı tatmak' tarifi altında bilmek" anlamına gelir. Eğer böyleyse, Vegemite'ı tatmanın bilgisi hem yetenek hem

$13 \mathrm{Bu}$ itirazlar, Mary'nin ilk defa kırmızı gördüğünde bazı bilişsel yetenekler kazanacağı iddiasına karşı değil, Mary'nin kırmızı görme deneyimine bağlı olarak yeni önermesel bilgi edinmeyeceği iddiasına karşı. Bu aşamada, genel kanıya şüpheyle yaklaşılıp yordam bilgisinin önermesel bilgiye indirgenip indirgenemeyeceği de sorgulanabilir. Örneğin, Stanley\&Williamson (2001) yordam bilgisinin önermesel bilgiye indirebileceğini ve dolayısıyla yetenek hipotezinin bilgi argümanına başarılı bir yanıt teşkil etmediğini savunuyor. Fakat, yordam bilgisinin diğer önermesel bilgilerden sunum kipi (mode of presentation) bakımından farklılaştığını iddia ediyorlar. Bu iddia, 5.3'te ele alacağım görüngüsel kavram stratejisi ile aynı temel mantığa dayandığından, burada bu konuya odaklanmayacağım. Görüngüsel kavram stratejisi hakkındaki tartışma, mutatis mutandis, bu iddiaya da uyarlanabilir. 
de önermesel bilgi (enformasyon) içerecektir. Buna katılmıyorum. Çünkü, açık ki, şunu söylemek anlamlı bir şey olurdu: "Bu deneyimi çok iyi biliyorum, bunun nasıl bir şey olduğunu çok uzun zamandır bilmekteyim, fakat bugün bu deneyimin Vegemite'ı tatma deneyimi olduğunu öğrendim." Ama, bu sözel soru önemsizdir (2004: 99).

Bu sözel soru, yani deneyimin hangi isim ya da nesnel tarif altında bilindiği sorusu önemsizdir, çünkü Lewis'e göre, bu zaten alelade bir önermesel bilgidir. Lewis'in iddiasını şu şekilde anlayabiliriz: Bir insan için “0, acıyı biliyor” dediğimizi düşünelim. "Biliyor" dediğimizde kişiye farklı türlerde bilgi atfediyor olabiliriz. Buradaki "bilmek" sözcüğünden kastımız önermesel bilgiye sahip olmak ise, şöyle bir şey kastediyor olabiliriz: “0, acı hakkında okumuş, araştırma yapmış ve acıya dair, acının biyolojisine, işlevine, nedenlerine, vs. dair gerçekleri öğrenmiş." Fakat, "bilmek" sözcüğünden kastımız önermesel olmayan bir tür bilgiye sahip olmak da olabilir. Mesela, şöyle bir şey kastediyor olabiliriz: “O, acıyı deneyimlemiş biri, acının nasıl bir şey olduğunu hayal edebiliyor, çekmiş olduğu acıları hatırlayabiliyor." İkinci örnekte, hakkında konuştuğumuz kişiye önermesel bilgi değil, sadece bazı yetenekler atfettik. Yetenek hipotezine göre de, görüngüsel bilgi, bu türden, önermesel olmayan, sadece bir takım bilişsel yeteneklere sahip olmaktan ibaret bir tür bilgi. Lewis, Mary'nin birinci türden, yani önermesel bilgisinin fizikselciliğe sorun çıkarmayacağını, çünkü bu bilginin özünde deneyime bağlı olmadığını iddia ediyor. Örneğin, Mary, kırmızı gördüğünde, yanlış bir şekilde "meğer yeşil görmek böyle bir șeymiş" deseydi, yanlışı sadece "şu anda gördüğüm domates yeşildir" önermesinin yanlışlı̆̆ına dayanacaktı, ki bu görüngüsel deneyimden bağımsız, tamamen nesnel bir iddiadır (bu cümlede "yeşildir" yükleminin domatese normal şartlar altında belli bir dalga boyuna sahip ışığı yansıtmasını sağlayan bazı fiziksel yüzey özellikleri atfettiğini düşünebiliriz). Fizikselcilik için sorun teşkil edebilecek gibi görünen öznel/görüngüsel bilgi ise, sadece deneyimle tanışıklığa dayalı bazı bilişsel yeteneklerden ibaret olduğundan, o da, aynı yüzme bilme örneğinde olduğu gibi, aslında fizikselcilik için bir sorun yaratmaz (yani, görüngüsel bilginin bilinçli deneyim içermesi bize bilinçli deneyimin fizikselliğinden şüphe etmek için hiçbir sebep vermez). 
Fakat, ne yazık ki, Lewis'in bu savunusu, tatmin edicilikten çok uzak. Öncelikle, Mary'nin “kırmızı görmek böyle bir şeymiş” diyerek ifade ettiği önerme, onun henüz odadayken, kırmızıyı deneyimlemeden önce bilebileceği bir önerme değil gibi duruyor, çünkü bu önermeyi kırmızı gördükten sonra öğreniyor. Yani, "kırmızı görmek böyle bir şeymiş" cümlesi "sözel bir soru"nun cevabı olabilir, fakat Mary'nin bu cevabı ancak kırmızıyı deneyimledikten sonra verebilmesi, bunun alelade (yani görüngüsellik içermeyen) bir önerme olmadığını gösteriyor. Eğer bu önerme Mary'nin kırmızı görme deneyimi edinmeden önce bilemeyeceği bir önerme ise, insan kırmızı renk algısına dair Mary'nin eksiksiz fiziksel bilgisi tarafından içerilmeyen doğru bir önerme var demektir, bu da tam olarak Jackson'ın vurguladığı nokta.

Nemirow (2007), buna karşılık olarak, Mary odadayken bu önermeyi öğrenemeyecek olsa bile, bu önermenin öğrenilemezliği önermenin anlaşılabilmesi için bazı bilişsel yeteneklerin edinilmesi gerekliliğine dayandığından yine, fizikselcilik açısından, bunun aslında yüzme bilmeme örneği kadar zararsız bir "bilgi eksikliği” olduğunu iddia ediyor. Fakat, Nemirow'un bu yanıtını da tatmin edici bulmuyorum, çünkü kişinin yüzme eyleminin mekaniğine, fiziğine dair, yüzme yeteneği edinmediği sürece kavrayamayacağı ve öğrenemeyeceği gerçekler yok (yine, fiziksel gerçeklerin nesnel olarak ifade edilebileceğini varsayıyoruz). 0 halde, Mary'nin görüngüsel deneyime dayalı bilişsel yetenekler edinmeden öğrenemeyeceği bir gerçek varsa, Jackson bu gerçeğin, eğer fiziksel bir gerçekse, neden bu kadar özel olduğunu sorabilir rahatlıkla bunu argümanında kullanabilir: Beynin fiziksel yapısı ve işlevlerine dair her gerçek, prensipte, yetenek hipotezinin görüngüsel bilgiyi oluşturduğunu iddia ettiği yetenekler kullanılmadan da bilinebilir, fakat kırmızı görme deneyimine dair görüngüsel gerçekler bu şekilde bilinemez, o halde bu görüngüsel gerçekler fiziksel/işlevsel gerçekler olamazlar.

Kaldı ki, bir gerçeği öğrenmenin görüngüsel deneyime dayanmayan bazı bilişsel yetenekler edinmeyi gerektirmesi oldukça sık karşılaştığımız bir olgu. 
Mesela, bir insanın "Pi'nin ilk on ondalık basamağı 1415926535'tir" önermesini öğrenmesi, bu on sayıyı hatırlayabilme ve sıralayabilme yeteneklerini elde etmesini gerektiriyor. Fakat, bu bilgi bazı bilişsel yeteneklere de dayansa, eğer bir insan bu önermeyi $t_{1}$ zamanında öğreniyorsa, $t_{1}$ 'den önce Pi'ye dair bilmediği doğru bir önerme vardı demektir.

Son olarak, yetenek hipotezinin bilgi argümanı karşısında etkisiz olduğunu argümanın farklı bir versiyonunu ele aldığımızda rahatlıkla fark edebiliriz ${ }^{14}$. Diyelim ki Mary'e, henüz odadayken, iki adet boya kalemi gösteriliyor. Bu kalemlerden ilki yeşil, ikincisi ise mavi. Fakat, kalemlerin üzerinde ne renk oldukları yazmadığı için, Mary bu kalemlerin hangisinin hangi renk olduğunu bilmiyor. Fakat, yine de, kalemleri gördükten sonra, Mary yeşil görme deneyiminin de mavi görme deneyiminin de önermesel olmayan görüngüsel bilgisine sahip. Yani, yetenek hipotezine göre, Mary mavi görme deneyimini de yeşil görme deneyimini de hayal etme, hatırlama ve tanıma yeteneklerini kazanmış durumda. Fakat, yine de, odadan çıkıp gökyüzüne baktığında "mavi görme deneyimi, benim ikinci kaleme baktığımda yaşadığım görsel deneyim imiş" diyor. Bu, Mary'nin mavi görme deneyimine dair öğrendiği yeni bir şey. Zaten bu deneyime dair fiziksel/nörolojik bütün gerçekleri biliyordu, fakat şimdi, daha önceden yaşamış olduğu bir görsel deneyimi bu fiziksel/nörolojik gerçeklerle bağdaştırabildi, onların birbirlerine denk düştügünü öğrendi. Yetenek hipotezi, Mary'nin gökyüzüne baktığında öğrendiği yeni gerçeği açıklamıyor, yalnızca Mary’nin mavi kalemi gördügünde öğrendiği, önermesel olmayan bilgiyi açıklıyor. Fakat, Mary'nin gökyüzüne baktığında öğrendiği gerçek de genel bir gerçek, ve Mary, odadayken, kalemleri gördükten sonra dahi, bu gerçeği sahip olduğu bilgiden çıkarsayamadı. Bunu, şuna benzetebiliriz: Mary, yüzmeye dair tüm fiziksel/biyolojik gerçekleri biliyor, daha sonra yüzme de öğreniyor, fakat ona öğrendiği șeyin “yüzme” olduğu

\footnotetext{
14 Bu argüman Stoljar'ın (2005) Deneyimli Mary ve Nida-Rümelin'in (2004) Marianna örneklerine dayanıyor. Benzer bir örnek, Chalmers (2004: 284-285) tarafından A-tipi materyalizme bir itiraz olarak kullanılıyor. Ayrıca, Warner (1986) ve Tye (2009: 134) da benzer senaryoları gündeme getiriyor.
} 
söylenmiyor. Mary'nin öğrendiği şeyin yüzme olduğunun kendisine söylenmesine ihtiyacı var mı? Yüzme hakkındaki tamamlanmış nesnel bilgiye sahip ise, yeni öğrendiği şeyin yüzme olduğunu bilememesi mümkün mü? Yüzme fiziksel bir aktivite olduğundan, Mary, öğrendiği şeyin yüzme olduğunu nesnel bilgisine dayanarak rahatlıkla bilebilecektir. Yani, denebilir ki, mavi ve yeşil kalemleri gördükten sonra, görsel deneyimlerine odaklanıp, bunların hangisinin mavi, hangisinin yeşil görme deneyimi olduğunu çıkarsayamaması, bu deneyimlerin tamamen fiziksel olduğu iddiasını yanlışlar. Görüldüğü gibi, Jackson'ın bilgi argümanı, ufak değişikliklerle, yetenek hipotezininin önermesel olmayan görüngüsel bilgi hakkındaki iddiasını da içine alacak şekilde yeniden kurgulanabilir.

\section{2. Tanışıklık Hipotezi}

Tanışıklık hipotezine göre de görüngüsel bilgi doğruluk değeri olmayan bir tür bilgidir. Tanışıklık, Conee'nin (1994: 144) terminolojisinde, bir şeyi kavramanın en dolaysız yoludur ${ }^{15}$. "Bilme" terimi, bu görüşe göre, yine çokanlamlıdır ve önermesel bilmeye atıfta bulunduğu gibi önermesel olmayan tanışıklığa atıfta bulunuyor olabilir. Mesela, “Frank Jackson'ı biliyorum” dediğimde, Frank Jackson hakkında önermesel bilgiye sahip olduğumu, mesela yazdığı makaleleri okuduğumu ifade ediyor olabileceğim gibi, Frank Jackson’la karşılaşmış, onunla tanışmış olduğumu ifade ediyor da olabilirim. Yani, eğer Frank Jackson'la kişisel olarak tanışmamışsam fakat sadece hakkında bazı bilgilere sahipsem, bir anlamda Frank Jackson'ı biliyorum, fakat bir anlamda da bilmiyorum. Conee'ye göre, Mary’nin odadan çıktığında kırmızı görme deneyimine dair edindiği bilgi, işte bu ikinci anlamdaki, yani tanışıklık anlamındaki önermesel olmayan bilgidir.

Görüldüğü gibi, tanışıklık hipotezi yetenek hipotezi ile aynı stratejiyi izlemekte, yani Mary’nin yeni bir şey öğrendiğini kabul etmekle birlikte, öğrendiği şeyin önermesel olmayan, yani bir gerçeği ifade etmeyen bir tür bilgi olduğunu

\footnotetext{
${ }^{15}$ Bu tür bilginin kavramsallaştırılması Bertrand Russell’a $(1910,1912)$ dayanmaktadır.
} 
iddia etmekte. Bu yüzden de, yukarıda yetenek hipotezine getirdiğimiz, Mary'nin odadan çıkıp kırmızı gördüğünde (ya da, argümanın ikinci versiyonunda, mavi gökyüzünde baktığında) öğrendiği şeyin önermesel bilgi içerdiği yönündeki itirazlarımız tanışıklık hipotezine de itiraz olarak ele alınabilir.

\section{3. Görüngüsel Kavram Stratejisi}

Horgan (1984), Loar (2004), Byrne (2002), Papineau (2002, 2007), Balog (2012a) gibi birçok fizikselci filozofa göre, fiziksel/nörolojik terimlerle, nesnel olarak kavramsallaştırabileceğimiz beyin durumlarımızı başka ve daha özel bir şekilde de, yani birinci kişi gözünden deneyimlediğimiz öznel görüngüsel niteliğe dayanarak da kavramsallaştırabiliyoruz. Buna dayanarak, bilgi argümanına şu itirazda bulunuluyor: Mary, ilk defa kırmızı gördüğünde yeni bir şey öğrendi, evet, fakat öğrendiği şey yeni bir gerçek değildi; öğrendiği şey daha önce fiziksel/nörolojik terimlerle kavramsallaştırdı̆̆ı nesnel bir gerçeğin birinci kişi gözünden nasıl kavramsallaştırılabileceği idi. Yani, Mary, daha önce sahip olmadı̆̆ı önermesel bir bilgi edindi, fakat bu yeni bilgi, daha önceden bildiği fiziksel bir gerçeğe dairdi, ve Mary'nin bu şekilde yeni bir önermesel bilgi edinmesinin fizikselciliğe aykırı hiçbir sonucu yok. Bilgi argümanına yapılan bu itirazı, Stoljar'ı (2005) takiben, "görüngüsel kavram stratejisi" olarak adlandıracağım.

Görüngüsel kavram stratejisine göre, deneyimlerimizin öznel bilgisi görüngüsel kavramlar içerir. Görüngüsel kavramlar, görüngüsel deneyimlerimize (ya da deneyimlerimizin öznel niteliğine) göndermede bulunur (ki eğer fizikselcilik doğruysa bu deneyimler ve öznel nitelik de aslında fizikseldir) ve bir görüngüsel kavram ancak göndermede bulunduğu deneyim yaşanarak edinilebilir ${ }^{16}$. Bu kavramlar, fiziksel/nörolojik kavramlara dayanarak analiz edilemezler.

\footnotetext{
16 Dennett'ın (2007) “Bataklık Mary’si” örneğindeki gibi, beynin bir yıldırım tarafından kırmızı görme deneyimini bilme durumuna geçirilmesi ve benzeri mucizevi kurgular hariç.
} 
$\mathbf{K}^{*}$ ve K kavramlarını ele alalım${ }^{17}$. Diyelim ki $\mathbf{K}^{*}$ bir görüngüsel kavram, K bir fiziksel kavram, ve $\mathbf{K}^{*}$ ve $\mathbf{K}$ aynı şeye, belli bir beyin durumuna göndermede bulunuyor. Mary, odadan çıkıp ilk defa kırmızı görme deneyimini yaşadığında, $\mathbf{K}^{*}$ kavramını ediniyor ve "kırmızı görme deneyimi, K* imiş" diye düşünüyor. Fakat, görüngüsel kavram stratejisine göre, Mary zaten kırmızı görme deneyiminin K olduğunu biliyordu. Yeni bir gerçek öğrenmedi, sadece kırmızı görme deneyiminin K olduğunu farklı bir şekilde kavramasına izin veren $\mathbf{K}^{*}$ kavramını öğrendi.

Burada önemli bir nokta, $\mathrm{K}=\mathrm{K}^{*}$ önermesinin a priori değil a posteriori doğru olması. Bunun nedeni de, yukarıda da belirttiğimiz gibi, görüngüsel kavramların fiziksel kavramlarla analiz edilememesi. Görüngüsel kavram stratejisine göre, "kırmızı görme deneyimi K'dır" inancı ile "kırmızı görme deneyimi $\mathrm{K}^{* \prime}$ dır" inancı arasındaki ilişki, "Süpermen $1,90 \mathrm{~m}$. boyundadır" ve "Clark Kent 1,90 m. boyundadır" inançları arasındaki ilişki gibidir. Bu iki inancın doğruluk değerleri zorunlu olarak aynıdır, çünkü bunlar aynı gerçeği farklı kavramlarla ifade eden iki inançtır. Yani, Clark Kent'in 1,90 boyunda olduğunu bilen bir insanın daha sonra Süpermen'in de 1,90 boyunda olduğunu öğrenmesi, daha önce Süpermen'in boyuna dair bu kişi tarafından bilinmeyen bir gerçek olduğunu göstermez, çünkü burada kişinin yaptığı şey daha önceden bildiği bir gerçeği yeni bir kavramı (Süpermen kavramını) kullanarak, farklı bir şekilde ifade etmek/kavramsallaştırmaktır.

$\mathrm{Bu}$ noktada, şöyle bir itiraz akla gelebilir: Tamam ama, bir kişi Süpermen=Clark Kent özdeşliğini öğrendiğinde yeni bir şey öğrenmiş olmuyor mu? Fregeci bir analizle, Süpermen=Clark Kent özdeşliğinin Süpermen=Süpermen özdeşliği ile aynı gerçeği ifade etmesine rağmen, bir totolojiden ibaret olmadığını, bilgilendirici olduğunu kabul etmek makul görünüyor. Bir insan Süpermen=Clark Kent özdeşliğini öğrendiğinde, Clark Kent'e (ve dolayısıyla Süpermen'e dair) yeni

\footnotetext{
17 Kavram ifaden bir terimi (ya da şematik harfi), o kavrama gönderme yapmak istediğim zaman koyu şekilde yazıyorum, aksi halde, kavramdan bahsetmek yerine o kavramı kullanıyorsam, terimi normal bir şekilde yazıyorum.
} 
bir şey öğrenmiş oldu; mesela gazetede muhabir olarak çalışmak ve uçabilmek özelliklerine aynı anda sahip olduğunu öğrendi. Aynı şekilde, Mary de $K=K^{*}$ özdeşliğini öğrendiğinde, bu iki kavram tek bir özelliğe göndermede bulunsa da, bu özelliğe dair yeni bir şey öğrenmiş sayılmaz mı?

Görüngüsel kavram stratejisine göre, Süpermen=Clark Kent özdeşliği ile $\mathrm{K}=\mathrm{K}^{*}$ özdeşliği arasında, ikisi de a posteriori önermeler olmalarına karşın, önemli bir fark var. Süpermen kavramının gönderimde bulunma şekli (sunum kipi - mode of presentation) mavi tayt giymek, kırmızı pelerin takmak, uçabilmek gibi özellikleri içeriyor. Clark Kent kavramı ise aynı kişiye gözlük takmak, Daily Planet gazetesinde muhabir olarak çalışmak gibi özellikler üzerinden göndermede bulunuyor. Fakat, bu özellikler zorunlu değil, olumsal özellikler. "Süpermen” ve "Clark Kent" terimlerinin gönderileni olan kişi, uçma yeteneğini kaybetse de, kıyafetlerini değiştirse de, gazetedeki işinden istifa etse de, hala aynı kişi (Kriptonlu Kal-El) olacak ${ }^{18}$. Loar (2004), K=K* özdeşliğinin farkının burada yattığını iddia ediyor: $\mathbf{K}$ ve $\mathbf{K}^{*}$ kavramlarının gönderimde bulunma şekli olumsal değil. K, kırmızı görme deneyiminin fiziksel/işlevsel tarifini kullanarak bu deneyime gönderimde bulunuyor. Fizikselcilik doğru ise, kırmızı görme deneyimi zorunlu olarak fiziksel/işlevsel bir durum olduğundan ${ }^{19}$, onun fiziksel/işlevsel tanımında içerilen tarifi, kırmızı görme deneyimi için zorunlu olarak doğrudur. $\mathbf{K}^{*}$ kavramı ise, kırmızı görme deneyiminin herhangi bir tarifini kullanmıyor, deneyimin kendisini kullanıyor. Yani, $\mathbf{K}^{*}$, gönderimde bulunduğu şeyi, ona gönderimde bulunmak için kullanıyor ${ }^{20}$.

\footnotetext{
18 "Süpermen"in bir betimleme değil özel isim olduğunu ve özel isimlerin katı gösteren olduklarını, yani bir özel ismin her zaman aynı tikele göndermede bulunduğunu varsayıyorum (Bkz. Kripke 1980).

19 Bir özelliğin fiziksel-özellik-olma veya işlevsel-özellik-olma gibi ikinci dereceden tür özelliklerinin özsel özellikler olduklarını varsayıyorum. Yani, eğer A özelliği fizikselse, hiçbir fiziksel özelliğin örneklenmediği fakat A özelliğinin örneklendiği bir mümkün dünya yoktur (aynısı ișlevselözellik-olma için de geçerli).

20 Görüngüsel kavramların, bir sunum kipi içermeden dolaysız bir şekilde göndermede bulunan cins-işaret kavramları olduğu iddiasını, bu görüş görüngüsel kavram stratejisini savunanların genel olarak kabul ettikleri bir görüş olmadığından, bu çalışmada ele almıyorum (Bkz. Levin 2017).
} 
Diyelim ki sağ elimde bir ağrı olduğunu söylemek istiyorum. "Sağ elim ağrıyor" dediğimde kullandığım sağ el kavramı, ağrı duyduğum yere nesnel ve aynı zamanda zorunlu özellikleriyle göndermede bulunuyor, yani el olmak ve vücudumun sağ tarafına bağlı olmak (eğer solda olsaydı ya da el olmasaydı, să̆ el olamazdı). Bir de, şöyle yaptığımı düşünün: sağ elimi kaldırıyorum, ve "ağrıyor!” diyorum. Yine, "sağ elim ağrıyor" cümlesini kullandığımda ifade ettiğim gerçeği ifade ettim, fakat bu sefer sağ elime göndermede bulunmak için sağ elimin kendisini kullandım. İşte, görüngüsel kavramlar da, buna benzer bir şekilde, göndermede bulundukları bilinç durumunu kullanırlar. Kırmızı görme durumu hakkında birinci kişi gözünden, görüngüsel kavram kullanarak düşünmek demek, bu görüşü savunan birçok felsefeciye göre, kırmızı görme deneyimini (ya da onun hatırlanan zihinsel imgesini) onun hakkında düşünmek için kullanmak demektir. Papineau (2002) ve Balog (2012b), bunu bir sözcükten bahsetmek için o sözcüğü tırnak içine almaya benzetir. Bu görüşe göre, nasıl ki "kırmızı" sözcüğünden (mesela sözcügün 7 harfli olduğundan) bahsederken sözcügün tırnak içine aldığım bir örneğini (token) kullanıyorum, aynı şekilde bir bilinç durumu hakkında düşünürken, onun bir örneğini kullanabilirim, ve bu da görüngüsel kavram kullanımına denk düşer.

Yukarıdaki itiraza dönecek olursak, görüngüsel kavram stratejisinin savunucularına göre, Süpermen=Clark Kent özdeşliğinin aksine, K=K* özdeşliği, gönderimde bulunulan şeyin özelliklerine dair empirik bir bilgi vermez. Kavramsal olarak da, K kavramına sahip biri, K* kavramını da deneyim yoluyla edinerek $\mathrm{K}=\mathrm{K}^{*}$ özdeşliğini öğrendiğinde, aslında K'ya dair yeni bir özellik öğrenmez, sadece K'yı K’ya göndermede bulunmak için kullanmış olur. Bu da, Papineau'ya göre, neden $\mathrm{K}=\mathrm{K}^{*}$ özdeşliğinin yanıltıcı bir şekilde bilgi vericiymiş gibi göründüğünü açıklar. Kırmızı görme deneyimi hakkında $\mathbf{K}^{*}$ kavramını kullanarak düşündügümüzde, de bu makalede de ele alınan türde, gönderileni sunum kipinde rol oynayan kavramlara dayalı versiyonlarının eleştirel bir değerlendirmesi için bkz. Demircioğlu 2013. 
deneyimi (ya da deneyimin zihinsel imgesini/hatırasını) kullanırız, fakat $\mathbf{K}$ kavramını kullandığımızda deneyimi değil, onun fiziksel tarifini kullanırız. Bu da K kavramının bir şeyleri dışarıda bıraktığı hissini uyandırır, çünkü $\mathbf{K}^{*}$ kavramını kullanmanın belli bir görüngüsel niteliği vardır. Fakat, K kavramı, aslında kırmızı deneyimine dair özsel hiçbir şeyi dışarıda bırakmaz, $\mathbf{K}^{* \prime}$ dan tek farkı, deneyimi kullanmamasıdır. Papineau (1993, 1995), bu iki kavramın gönderim yollarındaki farktan yola çıkarak gönderilenlerinin farklı olması gerektiğini düşünme hatasına "Antipatetik hata" adını veriyor ${ }^{21}$.

Görüngüsel kavram stratejisi, 5.1.in son kısmında bahsettiğimiz, hangi renk oldukları söylenmeden yeşil ve mavi boya kalemlerini gören Mary'nin durumunu da açlklıyor. Mary, bu senaryoda, mavi ve yeşil renkleri gördüğünde bu deneyimlere dair görüngüsel kavramları edinmesine karşın, halihazırda nesnel (fiziksel, işlevsel, vb.) kavramlarla ifade ettiği gerçekler arasından hangilerini bu yeni kavramları da kullanarak ifade edebileceğini sonradan öğreniyor. Fakat, yeni bir gerçek öğrenmiyor.

Görüngüsel kavram stratejisine getirilmiş olan en etkili itirazlardan biri Chalmers'ın (2007) temel argüman olarak adlandırdığı itirazdır. Chalmers görüngüsel kavram stratejisine eleştirisini fizikselcilik karşıtı kavranabilirlik (felsefi zombi) argümanı ${ }^{22}$ çerçevesinde dile getiriyor, fakat itirazının özünü şu şekilde ifade edebiliriz:

Görüngüsel kavram kavramının kendisi görüngüsel bir kavram mı yoksa fiziksel/işlevsel bir kavram mıdır? Eğer görüngüsel kavram görüngüsel bir kavramsa, bu kavramı kullanan bir açıklama, görüngüsel bilginin ne olduğunu fiziksel/işlevsel terimlerle ifade etmekte yetersiz kalır. Eğer görüngüsel değil de fiziksel/işlevsel bir kavramsa, bu sefer de görüngüsel bilgimizin ayrılmaz bir

${ }^{21}$ Arıcı (2020), "ayrıkllk sezgisi”nin ya da K=K* özdeşliğinin bilgi verici görünmesinin antipatetik hata ile açıklanabilirliğinin yeterli bir yanıt olmadığını, fizikselcilerin antipatetik hata açıklamasının zihin durumlarının fiziksel olmadığı açıklamasından daha güçlü olduğunu da göstermeleri gerektiğini vurguluyor.

22 Bkz. Kirk (2021) 
parçası olanı öznel deneyimimizi ve dolayısıyla kendi zihin içeriğimize dair epistemik durumumuzu ifade etmekte yetersiz kalır. Yani, her halükarda, görüngüsel kavramlara atıfta bulunan bir açıklamayı fizikselcilerin kabul edilir bulmaması gerekir, çünkü bu açıklama ya sadece fiziksel/işlevsel terimleri kullanan bir açılama olmayacak ya da öznel epistemik durumumuzun açıllanmaya muhtaç önemli bir boyutunu görmezden gelecektir.

Chalmers'ın temel argümanına Balog (2012a), görüngüsel kavram stratejisinin ruhunu yansıtacak şekilde şöyle karşllık veriyor: Görüngüsel kavram kavramı fiziksel bir gerçekliğe (beynin fiziksel/işlevsel bir durumuna) atıfta bulunmaktadır, fakat bu gerçekliğe hem fiziksel/işlevsel terimlerle hem de görüngüsel bir kavramla atıfta bulunmak mümkündür. Yani, biri fiziksel/işlevsel diğeri görüngüsel olmak üzere aslında iki farklı "görüngüsel kavram" kavramımız vardır. Bunların içinden fiziksel/işlevsel olanla fiziksel bir açılklama verilebilirken, görüngüsel olanıyla da öznel epistemik durumumuz anlaşllabilir. Balog, böylece, bilgi argümanına fizikselci bir yanıt olarak öznel deneyimimizin görüngüsel bilgisini açıklamak için kullanılan görüngüsel kavram stratejisini, bir üst seviyeye çıkarak, görüngüsel bilgimiz hakkındaki bilgimizi fizikselcilikle uygun olacak şekilde açıklamak için de kullanıyor.

Balog'un Chalmers'a cevabının görüngüsel kavram stratejisini kabul eden bir insanı tatmin edecek, onun tarafından makul bulunacak doğal bir açıklama olduğuna katılıyorum. Fakat, görüngüsel kavram stratejisinin doğruluğundan şüphe etmek için başka gerekçelerimiz olduğunu düşünüyorum.

İki beyin durumu düşünelim (bunlar fiziksel/işlevsel durumlar). Bu beyin durumlarının ilki kırmızı rengi görmenin bilinçli deneyimine, diğeri ise gri görmenin bilinçli deneyimine karşılık geliyor (bu karşılık gelme, birçok fizikselciye göre, özdeşliktir). Kırmızı görme deneyimine karşılık gelen beyin durumuna “KB," gri gören beyin durumuna da "GB" adını verelim. KB ve GB arasında birçok fiziksel/işlevsel fark var. Bu iki beyin durumundan sadece KB’nin sahip olup 
GB’nin sahip olmadığı tüm elektrokimyasal, nöronal, yapısal, işlevsel, vs. özelliklerin bir listesini çıkaralım. Bu, KB'nin GB'den fiziksel/işlevsel farklarının bir listesi. Mary, bu listeyi henüz odadayken biliyordu. Buna "Liste1" diyelim. Soru şu: Mary ilk defa kırmızı rengi gördüğünde KB'nin GB'den yeni bir farklı olma şeklini öğrendi mi? Mary, kırmızı gördüğünde "Liste2" adında yeni bir liste yapsın. Liste1, Liste2 ile özdeş midir, yoksa Liste2'de KB deneyiminde olup GB deneyiminde olmayan yeni bir özelliğe, Liste1'de ifade edilememiş bir farka yer verilmiş midir? Liste1'i bilen fakat Liste2'yi bilmeyen biri, KB'nin GB'den her farkına vakıf mıdır?

Sezgisel olarak, Liste2'de belirtilen özelliklerin Liste1'de belirtilen özelliklere sadece epistemik olarak değil, ontolojik olarak da indirgenemeyeceği, yani iki liste arasında sadece kullandıkları kavramlar açısından değil, atıfta bulundukları özellikler açısından da fark olduğunu düşünüyorum. Bu, Frank Jackson'ın da apaçık bir gerçek olarak gördüğü, sezgisel bir kabul. Fakat, görüngüsel kavram stratejisi doğruysa, bu sezgi yanlış olmalı. Yani, fizikselci bir bakış açısından, şu argüman sunulabilir:

Argüman1:

1. Görüngüsel kavram stratejisi doğru ise, $\mathrm{KB}$ ve $\mathrm{GB}$ arasında Liste2'de olup Liste1'de olmayan bir fark yoktur.

2. Görüngüsel kavram stratejisi doğrudur.

3. $O$ halde, KB ve GB arasında Liste2'de olup Liste1'de olmayan bir fark yoktur.

Fakat, G. E. Moore’un (1939) dış dünya şüpheciliğine itirazında kullandığı yöntemden esinlenerek, Argüman1'in karşısına şöyle bir argüman çıkarılabilir:

\section{Argüman2:}

1. Görüngüsel kavram stratejisi doğru ise, $\mathrm{KB}$ ve GB arasında Liste2'de olup Liste1'de olmayan bir fark yoktur.

2. KB ve GB arasında Liste2'de olup Liste1'de olmayan bir fark vardır.

3. 0 halde, görüngüsel kavram stratejisi yanlıştır. 
Bu iki argüman, ilk öncüllerinde aynı koşullu önerme olan bir Modus Ponens bir de Modus Tollens. Bu iki argümanın ikisi birden sağlam olamayacağından, en az birini reddetmemiz gerekiyor. Bunun için de sormamız gereken soru şu: Argüman1'in mi yoksa Argüman2'nin mi ikinci öncülü daha kabul edilebilirdir? Bu aşamada işin çıkmaza girdiğini ve sezgiler arası bir çatışmaya vardığımızı düşünüyorum. Bana Argüman2'nin ikinci öncülünün doğruluğu Argüman1'in ikinci öncülünün doğruluğundan çok daha kabul edilebilir geliyor, fakat benimle hemfikir olmayan birini buna nasıl ikna edebileceğimi bilmiyorum. Aynı şekilde, benim sezgimi paylaşmayan birinin de bana ikna edici bir argüman sunabileceğini düşünmüyorum, çünkü benim için Liste1 ve Liste2'nin farklı olduğuna dair sezgim oldukça temel bir sezgi ve bu sezgimin yanlışlığına dair sunulacak (mesela Papineau'nun Antipatetik Hata'sına atıfta bulunan) bir argümanın öncüllerinin dayandığı felsefi-teorik-bilimsel iddiaları (ya da bu iddialardan en az birini) reddetmek daha makul olacaktır. Bu noktada, yani Argüman1 ve Argüman2'nin sağlamlıklarının karşılaştırılması noktasında, görüngüsel kavram stratejisinin savunucuları ile karşıtları arasındaki rasyonel diyalektiğin tıkandığı kanaatindeyim..$^{23}$

\section{Sonuç}

Frank Jackson'ın bilgi argümanına getirilen fizikselci itirazların hiçbirinin argümanı reddetmemiz için bize güçlü bir sebep sunmadığını savundum. Amacım bilgi argümanının sağlamlığını kanıtlamak değildi. Fizikseli farklı tanımlayan biri, Jackson'la görüngüsel bilincin bilimsel açıklamasının olanaksızlığg konusunda hemfikir olup yine de görüngüsel bilincin fiziksel bir olgu olduğu iddiasını savunabilir. Görüngüsel kavram stratejisine getirdiğim eleştiride belirttiğim gibi, bu stratejiyi takip eden biri, farklı bilinçli deneyimler yaşayan iki beyin durumu arasındaki fiziksel/işlevsel farkların listesini öğrenen bir insanın, bu iki beyin durumu arasında, bu deneyimleri daha sonra yaşadığında öğreneceği başka bir

\footnotetext{
${ }^{23}$ Bu görüşün daha detaylı bir savunusu için bkz. Kıymaz 2019a.
} 
farkın kalmadığını iddia edebilir. Bu iddiaya sahip bir insan, benim bariz (selfevident) olarak nitelendirdiğim bir gerçeği reddediyordur ve bu aşamada uslamlama işlevsizleşir. Bu tür fikir ayrılıklarının olabileceğini ve bilgi argümanını bu şekilde reddetmenin mümkün olduğunu kabul etmekle birlikte, bu reddedişlerin bazı fiziksel özelliklerin nesnel olarak ifade edilemeyeceği ya da birinci kişi gözünden algllanan gerçekliğin üçüncü kişi perspektifinden de tam olarak bilinebileceği gibi oldukça tartışmalı felsefi kabuller gerektirdiğini, bu yüzden de teorik olarak maliyetli olduklarını düşünüyorum. Bu maliyeti kabul eden felsefeciler elbette ki var, fakat, bu makalede göstermeye çalıştığım üzere, bu maliyeti kabul etmemek ve bilgi argümanını savunarak fizikselciliği reddetmek de hala makul bir felsefi pozisyondur. 


\title{
A Defense of the Knowledge Argument against Physicalism
}

\author{
Summary \\ Tufan KIYMAZ \\ Assist. Prof. Dr. \\ Bilkent University, Faculty of Humanities and Letters, Department of Philosophy, Ankara, TR \\ ORCID: 0000-0002-6631-3857 \\ tufankiymaz@gmail.com
}

\section{Introduction}

Frank Jackson's (1982, 1986) knowledge argument against physicalism is as follows: Mary is a super-scientist who has complete physical knowledge (that is, knowledge that can be expressed in physical, functional, mathematical and logical terms) about human color vision. So, if physicalism is true, she knows all general facts about human color vision. But, she lives in a black-and-white room and she has never seen colors. One day, she leaves the room and sees a red tomato. Upon seeing red for the first time, she exclaims: "So, this is what it is like to see red!" Seemingly, she learned a new general fact about human color vision, namely she learned what people see when they see red (under normal conditions). But, this means that this new fact is not a physical fact, since she already knew those. So, physicalism is false.

Let's write this argument in more detail, based on Nida-Rümelin's (2015) characterization of the argument:

\section{First Premise:}

P1: Mary has complete physical knowledge about human color vision before her release.

First Conclusion: (from P1)

C1: Mary knows all the general physical facts about human color vision before her release.

Second Premise:

P2: Upon seeing red for the first time, Mary learns something about human color vision.

Second Conclusion: (from P2)

C2: There are some general facts about human color vision that Mary does not know before her release.

Final Conclusion: (from C1 and C2)

C3: There are non-physical facts about human color vision. 
The inference from $\mathrm{C} 1$ and $\mathrm{C} 2$ to $\mathrm{C} 3$ is valid. So, there are four possible ways to object to this argument: (i) P1 is false, (ii) C1 does not follow from P1, (iii) P2 is false, (iv) $\mathrm{C} 2$ does not follow from P2. Below, I discuss these four types of objection and defend the knowledge argument.

\section{Objections to the First Premise}

P1: Mary has complete physical knowledge about human color vision before her release.

According to Jackson, Mary's pre-release physical knowledge is general knowledge that can be expressed in broadly physical (both micro-physical and macrophysical) terms. P1, which states that Mary has complete physical knowledge about human color vision before her release, is acceptable to both antiphysicalists and physicalists. A few objections to $\mathrm{P} 1$ in the literature rest on some simple misunderstandings. For example, Stemmer (1989 p. 90 n. 6) argues that this premise is problematic because of the element of self-reference, which arises from the fact that knowing is, at least partly, a physical process, and hence Mary's complete physical knowledge must include itself. But this objection rests on a confusion of general and particular physical knowledge. Mary has complete general knowledge, she is not supposed to be omniscient about every particular fact that is expressible in physical terms.

\section{Objections to the First Inference}

P1: Mary has complete physical knowledge about human color vision before her release.

C1: Mary knows all the general physical facts about human color vision before her release.

\section{1. Conceptions of the Physical}

As an objection to the inference from $\mathrm{P} 1$ to $\mathrm{C} 1$, some argue that it is possible that Mary has complete physical knowledge but she does not know every (general) physical fact, because there are physical facts that cannot be expressed in physical terms. Flanagan (1992), Bealer (1994), Alter (1998), Van Gulick (2004), and most notably Howell $(2008,2013)$ defend this view. They argue that physicalism is compatible with the existence of physical facts that Mary cannot learn just from discursive lessons; physicalism is a metaphysical view and not a linguistic/epistemological view.

One problem with these views, as Nida-Rümelin (2015) points out, is that it is difficult to make sense of the term "physical fact," if it does not mean a fact expressible 
in physical terminology (See Kiymaz 2019c for a discussion of different conceptions of the physical).

\section{2. Deduction Requires Experience}

Let $\mathrm{Q}$ be the proposition "this is what it is like to see red" and let $\mathrm{P}$ be complete physical knowledge. Montero (1999) argues that it might be the case that pre-release Mary cannot deduce $Q$ from $P$ only because she cannot comprehend $Q$ without first experiencing what it is like to see red. And, if she can deduce $Q$ from $P$ once she becomes capable of understanding $Q$ by seeing red, this would still mean that the knowledge argument is unsound.

However, it is not easy to see how one can deduce $Q$ from $P$ in this case. $Q$ is a proposition that can only be apprehended via a subjective experience, and $\mathrm{P}$ is a proposition that can be expressed objectively in physical/functional terms. If the concepts in $Q$ are not analyzable in terms of the concepts in $P$, then it is not clear with which valid inference one can deduce $Q$ from $P$.

\section{Objections to the Second Premise}

P2: Upon seeing red for the first time, Mary learns something about human color vision.

\section{1. The Lack of Detail in the Argument}

Thompson (1995, p. 264) argues that Mary, before her release, could have the phenomenal knowledge of what it is like to see red, because she could see colors without leaving her room; for example, she will still see the color of her own body or she could see colors when she rubs her eyes or when she dreams.

Maybe people with intact visual systems do experience colors in their dreams or as a result of random firings in their visual cortex, but this can only be a problem for Jackson's argument if this is necessarily the case. And, it is not. The thought experiment requires only the possibility of a person with intact visual system, who never rubs her eyes, has never seen, dreamt, or imagined colors.

\section{2. The Possibility of Imagining}

Churchland (1985), Maloney (1985: 34) and Dennett (2007: 23) claim that prerelease Mary can learn what it is like to see red because she can imagine red based on her physical knowledge of the red seeing experience. So, they claim that the knowledge argument is unsound since the second premise is false: When Mary sees red for the first time she wouldn't be surprised; she would just say "this is exactly like I imagined."

However, this objection rests on a straw man fallacy. Jackson does not claim that pre-release Mary cannot imagine red. Jackson's following remarks about Fred, who has a color experience that we do not have, makes it clear that the knowledge 
argument is not about imagination: "If Physicalism were true, enough physical information about Fred would obviate any need to extrapolate or to perform special feats of imagination or understanding in order to know all about his special color experience. The information would already be in our possession. But it clearly isn't. That was the nub of the argument." (Jackson 1982, p. 132).

Jackson makes it clear that his argument is about Mary's inability to logically deduce a phenomenal truth from physical truths, and not her inability to imagine.

\subsection{The Possibility of Deduction from Physical Knowledge}

For another objection to P2, Churchland (1985, p. 25-28) and Dennett (2004, pp. $60-61$; 2007) argue that the knowledge intuition is prima facie powerful only because of our lack of understanding of what complete physical knowledge would be. They maintain that it is question begging to just assume that a person with complete physical knowledge will learn something new when she has a new phenomenal experience.

Dennett (2007) proposes a possible way in which Mary can deduce phenomenal knowledge from physical knowledge without imagining or experiencing the phenomenal state in question, but he fails to show that phenomenal knowledge is logically deducible from physical knowledge. His proposed method of deduction involves putting oneself in the state of knowing what it is like to see red by manipulating one's brain. But, this is not logically deducing phenomenal knowledge from physical knowledge; this is using physical knowledge as an instruction to gather phenomenal knowledge. ${ }^{24}$

\subsection{Social Externalism}

According Ball (2009) and Tye (2009), a phenomenal concepts is like any other concept and it can be used deferentially without a full grasp of the concept. Ball, based on this claim, argues that Mary, before her release, uses the phenomenal concept of what it is like to see red deferentially, which enables her to know what it is like to see red, even though she cannot fully understand it. So, when she sees red for the first time, she doesn't learn a new fact, she just acquires a fuller understanding of a fact she already knows.

Ball's objection to the knowledge argument is not plausible. As Alter (2013) points out, we can propose the following version of the knowledge argument to circumvent the social externalism objection: Pre-release Mary has full understanding of physical facts. Pre-release Mary doesn't have full understanding of phenomenal facts. Therefore, phenomenal facts are not physical facts.

${ }^{24}$ For a detailed evaluation of Dennett's proposal, see Kıymaz 2020. 


\section{Objections to the Second Inference}

P2: Upon seeing red for the first time, Mary learns something about human color vision.

C2: There are some general facts about human color vision that Mary does not know before her release.

\section{1. The Ability Hypothesis}

Lewis $(1983,2004)$ and Nemirow $(1980,1990)$ argue that Mary does not learn new factual/propositional knowledge when she experiences a new phenomenal state, but she gains some cognitive abilities, which constitute not knowledge-that but knowhow. According to Lewis (2004), knowing what it is like to have a certain experience consists in the possession of the abilities to recognize, imagine, and remember the experience.

However, Crane (2003) and Loar (2004) note that what Mary learns when she sees red has truth value: upon seeing a red tomato, she expresses a proposition by the sentence "so, this is what it is like to see red" because this sentence might have been false (if, for example, what she saw was a green tomato), but this proposition was not epistemically available for her while she was still in the room.

Furthermore, suppose we show pre-release Mary two crayons, a green one and a blue one, without telling her which is which ${ }^{25}$. Now she has experienced what it is like to see green and what it is like to see blue (whithout being able to identify them as such). Now, she has the relevant know-how; the abilities to imagine, remember and recognize these phenonmenal experiences. But, imagine she then leaves the room, sees the blue sky, and says "so, that (talking about her experience of seeing the second crayon) is what it is like to see blue." Apparently, she learned a new fact, however, she learned this even though she already had the phenomenal know-how. So, the ability hypothesis is not an adequate account of what Mary learns when she leaves the room.

\section{2. The Acquaintance Hypothesis}

Earl Conee (1994) argues that Mary's new phenomenal knowledge is not propositional knowledge, but nonpropositional acquaintance knowledge. According to Conee (1994, p. 144), acquaintance knowledge consists in the most direct way of apprehending a thing. To become acquainted with a city is to visit the city, and to become acquainted with a property is to experience the property, or, more precisely, to have the property as a subject. So, Mary's new knowledge does not pose a threat to physicalism, since it is nonpropositional and the phenomenal property that she becomes acquainted with can be a physical/functional property.

I believe that the above objection to the ability hypothesis can be applied to the acquaintance hypothesis too (since they both deny that post-release Mary learns new propositional knowledge).

25 This example is inspired by Stoljar (2005) and Nida-Rümelin (2004). 


\section{3. Phenomenal Concept Strategy}

According to Horgan (1984), Loar (2004), Byrne (2002), Papineau (2002, 2007), and Balog (2012a), among others, Mary's new phenomenal knowledge is propositional knowledge about the physical facts that she already has physical knowledge about. Phenomenal knowledge is knowledge that involves phenomenal concepts, and (excluding miracles) phenomenal concepts can only be acquired by phenomenal experience. A phenomenal concept picks out its reference directly by using the reference itself (according to the most common account). What a phenomenal concept picks out, according to this view, is a physical property. So, what Mary learns upon seeing a red tomato is not a new truth, but a new way of apprehending a truth that she already knows.

The plausibility of the phenomenal concept strategy is debatable. I believe that, at the point we are currently at, the dialectic between proponents and opponents of the phenomenal concept strategy is stuck. Here is why: Let's say GB is the brain state of consciously perceiving gray under normal conditions, and RB is the brain state of consciously perceiving red under normal conditions. Pre-release Mary makes a list of the ways RB is different from GB, that is, the list of the properties that RB has but GB does not. Let's call this "List1." Now, Mary leaves the room, sees a red tomato, and makes a new list of the differences between RB and GB. Call this "List2." Intuitively, in List2, there is a phenomenal property that does not appear in List1, namely, the subjective property of what it is like to be in GR. But, this is the intuition that is disputed by the phenomenal concept strategists. Consider these two arguments:

Argument1:

1. If phenomenal concept strategy is true, then List2 does not have a new item that is not in List1.

2. Phenomenal concept strategy is true.

3. Therefore, List2 does not have a new item that is not in List1.

Argument2:

1. If phenomenal concept strategy is true, then List2 does not have a new item that is not in List1.

2. List2 has a new item that is not in List1.

3. Therefore, phenomenal concept strategy is false.

Both arguments are valid and the first premises are the same. So, the question is whether the second premise of Argument1 or the second premise of Argument2 is more plausible. I find Argument2 more plausible, but, at this stage, I think we have reached at a clash of intuitions. ${ }^{26}$

\footnotetext{
${ }^{26}$ See Kiymaz 2019a for a detailed defense of this position.
} 


\section{Conclusion}

My aim here was not to prove that the knowledge argument is sound, but to show that none of the objections that are discussed are strong enough to refute the knowledge argument. It is not unreasonable to believe that the knowledge argument is sound and physicalism is false. 


\section{KAYNAKÇA | REFERENCES}

Alter, T. (1998). A Limited Defense of the Knowledge Argument. Philosophical Studies, 90 (1), 35-56.

Alter, T. (2008). Phenomenal Knowledge without Experience. The Case for Qualia (ed. Edmond Wright). MIT Press. (486).

Alter, T. (2013). Social Externalism and the Knowledge Argument. Mind, 122

Arıcl, M. (2020). The Source of Anti-Physicalist Arguments: The Unbridgeable Gap between the Phenomenal and the Physical. MetaZihin: Yapay Zeka ve Zihin Felsefesi Dergisi, 3 (2), 99-119. 962.

Ball, D. (2009). There Are No Phenomenal Concepts. Mind, 118 (472): 935-

Balog, K. (2012a). In Defense of the Phenomenal Concept Strategy. Philosophy and Phenomenological Research, 84 (1), 1-23.

Balog, K. (2012b). Acquaintance and the Mind-Body Problem. New Perspectives on Type Identity: The Mental and the Physical. (ed. S. Gozzano \& C. S. Hill, pp. 16-43). Cambridge University Press.

Bealer, G. (1994). Mental Properties. The Journal of Philosophy, 91 (4), 185208. Kegan Paul.

Broad, C. D. (1925). The Mind and its Place in Nature. London: Routledge and

Burge, T. (1979). Individualism and the Mental. Midwest Studies in Philosophy, 4 (1), 73-122.

Burge, T. (1986). Intellectual Norms and the Foundations of Mind. Journal of Philosophy, 83, 697-720. 123-140.

Byrne, A. (2002). Something about Mary. Grazer Philosophische Studien, 62,

Chalmers, D. J. (1996). The Conscious Mind. New York: Oxford University Press.

Chalmers, D. J. (2004). Phenomenal Concepts and the Knowledge Argument. There's Something About Mary: Essays on Phenomenal Consciousness and Frank Jackson's Knowledge Argument (ed. P. Ludlow, D. Stoljar \& Y. Nagasawa). MIT Press.

Chalmers, D. J. (2007). Phenomenal Concepts and the Explanatory Gap. Phenomenal Concepts and Phenomenal Knowledge: New Essays on Consciousness 
and Physicalism (ed. T. Alter and S. Walter, pp. 167-194). Oxford: Oxford University Press.

Chalmers, D. J. \& F. Jackson (2001). Conceptual Analysis and Reductive Explanation. Philosophical Review, 110, 315-60.

Churchland, P. M. (1985). Reduction, Qualia and The Direct Introspection of Brain States. Journal of Philosophy, 82 (January), 8-28.

Conee, E. (1994). Phenomenal Knowledge. Australasian Journal of Philosophy, 72 (2), 136-50.

Crane, T. (2003). Subjective Facts. Real Metaphysics: Essays in Honour of D. H. Mellor (ed. H. Lillehammmer \& G. Rodrigez-Pereyra, pp. 68-83). New York: Routledge.

Çağatay, H. \& C. Ekemen (2011). Mary'nin Odası ve Fizikalizm. Felsefe Tartışmaları, 47, 26-33.

Demircioğlu, E. (2013). Physicalism and Phenomenal Concepts. Philosophical Studies, 165 (1), 257-277.

Dennett, D. C. (2007). What RoboMary Knows. Phenomenal Concepts and Phenomenal Knowledge (ed. T. Alter and S. Walter). Oxford University Press. Press.

Flanagan, O. J. (1992). Consciousness Reconsidered. Cambridge, Mass: MIT

Horgan, T. (1984). Jackson on Physical Information and Qualia. Philosophical Quarterly, 34, 147-52.

Howell, R. J. (2008). Subjective Physicalism. The Case for Qualia (ed. Edmond Wright). MIT Press.

Howell, R. J. (2013). Consciousness and the Limits of Objectivity: The Case for Subjective Physicalism. Oxford University Press.

Jacquette, D. (1995). The Blue Banana Trick: Dennett on Jackson's Color Scientist. Theoria, 61 (3), 217-30.

Jackson, F. (1982). Epiphenomenal Qualia. The Philosophical Quarterly, 32 (127), 127-36.

Jackson, F. (1986). What Mary Didn't Know. The Journal of Philosophy, 83 (5), 291-95.

Jackson, F. (1998). From Metaphysics to Ethics. Oxford: Oxford University Press.

Jackson, F. (2004). Mind and Illusion. There's Something about Mary: Essays on Phenomenal Consciousness and Frank Jackson's Knowledge Argument (ed. P. Ludlow, D. Stoljar \& Y. Nagasawa). MIT Press. 
Kıymaz, T. (2019a). Phenomenal Concepts and Physical Facts: A Dialogue with Mary. Filozofia: Journal for Philosophy, 74 (10), 797-807

Kıymaz, T. (2019b). What Gary Couldn't Imagine. Journal of Philosophical Research, 44, 293-311.

Kiymaz, T. (2019c). Subjective Physicalism as a Response to the Knowledge Argument. MetaZihin, 2 (2), 199-211.

Kıymaz, T. (2020). A Priori Physicalism and the Knowledge Argument. Teorema, 39 (2), 87-103 (1), 49-69

Kıymaz, T. (2021). Zihin Felsefesinde Fizikselin Tanımı Sorunu. Kaygı, 20

Kirk, R. (2021). Zombies. The Stanford Encyclopedia of Philosophy. Erişim tarihi: 01.08.2021.

(https://plato.stanford.edu/archives/spr2021/entries/zombies).

Kripke, S. (1980). Naming and Necessity. Harvard University Press.

Levin, J. (2007). What is a Phenomenal Concept? Phenomenal Concepts and Phenomenal Knowledge (ed. T. Alter \& S. Walter). New York: Oxford University Press.

Levine, J. (1983). Materialism and Qualia: The Explanatory Gap. Pacific Philosophical Quarterly, 64 (October), 354-61.

Lewis, D. (1983a). Postscript to "Mad Pain and Martian Pain." Philosophical Papers, 12, 130-133.

Lewis, D. (1983b). New Work for a Theory of Universals. Australasian Journal of Philosophy, 61, 343-77.

Lewis, D. (2004). What Experience Teaches. There's Something About Mary: Essays on Phenomenal Consciousness and Frank Jackson's Knowledge Argument (ed. P. Ludlow, D. Stoljar \& Y. Nagasawa). MIT Press.

Loar, B. (2004). Phenomenal States (Revised Version). There's Something about Mary: Essays on Phenomenal Consciousness and Frank Jackson's Knowledge Argument (ed. P. Ludlow, D. Stoljar \& Y. Nagasawa). MIT Press.

Maloney, J. C. (1985). About Being a Bat. Australasian Journal of Philosophy, 63 (1), 26-49.

Montero, B. (1999). The Body Problem. Nous, 33, 183-200.

Moore, G. E. (1939). Proof of an External World. Proceedings of the British Academy, 25, 273-300.

Nagel, T. (1974). What is it like to be a Bat?". Philosophical Review, 83 (October), 435-50. 
Nemirow, L. (1980). Review of Nagel's Mortal Questions. Philosophical Review, 89, 473-477.

Nemirow, L. (1990). Physicalism and the Cognitive Role of Acquaintance. Mind and Cognition: A Reader (ed. W. Lycan). Oxford: Blackwells.

Nemirow, L. (2007). So, This is What It's Like: A Defense of the Ability Hypothesis. Phenomenal Concepts and Phenomenal Knowledge (ed. T. Alter \& S. Walter). Oxford University Press.

Nida-Rümelin, M. (2004). What Mary Couldn't Know: Belief About Phenomenal States. There's Something About Mary: Essays on Phenomenal Consciousness and Frank Jackson's Knowledge Argument (ed. P. Ludlow, D. Stoljar \& Y. Nagasawa). MIT Press.

Nida-Rümelin, M. (2015). Qualia: The Knowledge Argument. The Stanford Encyclopedia of Philosophy. Erişim Tarihi: 01.07.2021. (http://plato.stanford.edu/archives/sum2015/entries/qualia-knowledge/).

Papineau, D. (1993). Physicalism, Consciousness and the Antipathetic Fallacy. Australasian Journal of Philosophy, 71 (2), 169-183.

Papineau, D. (1995). The Antipathetic Fallacy and the Boundaries of Consciousness. Conscious Experience (ed. Metzinger, T.). Ferdinand Schoningh.

Papineau, D. (2002). Thinking about Consciousness. Oxford: Clarendon Press.

Papineau, D. (2007). Phenomenal and Perceptual Concepts. Phenomenal Concepts and Phenomenal Knowledge (ed. T. Alter \& S. Walter, pp. 111-144). Oxford University Press.

Putnam, H. (1970). Is Semantics Possible?. Metaphilosophy, 1 (3), 187-201.

Putnam, H. (1975). The Meaning of 'Meaning.' Minnesota Studies in the Philosophy of Science, 7, 131-193.

Russell, B. (1910). Knowledge by Acquaintance and Knowledge by Description. Proceedings of the Aristotelian Society, 11, 108-128. Press.

Russell, B. (1912). The Problems of Philosophy. Oxford: Oxford University

Ryle, G. (1949). The Concept of Mind. Hutchinson \& Co.

Spurrett, D. \& D. Papineau (1999). A note on the Completeness of 'Physics'. Analysis, 59 (1), 25-29.

Stanley, J. \& Willlamson, T. (2001). Knowing How. Journal of Philosophy, 98 (8), 411-444.

Stoljar, D. (2005). Physicalism and Phenomenal Concepts. Mind \& Language, 20 (5), 469-94. 
Stoljar, D. (2021). Physicalism. The Stanford Encyclopedia of Philosophy. Erişim Tarihi: 01.07.2021. (https://plato.stanford.edu/archives/sum2021/entries/physicalism).

Strawson, G. (2006). Realistic Monism - why Physicalism Entails Panpsychism. Journal of Consciousness Studies, 13 (10-11), 3-31.

Thompson, E. (1995). Colour Vision: A Study in Cognitive Science and Philosophy of Science. Routledge.

Tye, M. (2009). Consciousness Revisited: Materialism Without Phenomenal Concepts. MIT Press.

Uslu, A. K. (2021). Can We Explain Qualia without Immaterial Properties?. FLSF, 31, 37-50.

Van Gulick, R. (2004). So Many Ways of Saying No to Mary. There's Something About Mary: Essays on Phenomenal Consciousness and Frank Jackson's Knowledge Argument (ed. P. Ludlow, D. Stoljar \& Y. Nagasawa). MIT Press.

Warner, R. (1986). A Challenge to Physicalism. Australasian Journal of Philosophy, 64 (September), 249-65.

Wilson, J. M. (2006). On Characterizing the Physical. Philosophical Studies, 131 (1), 61-99. 